Article

\title{
Fermented Seeds ("Zgougou") from Aleppo Pine as a Novel Source of Potentially Probiotic Lactic Acid Bacteria
}

\author{
Jihen Missaoui ${ }^{1,2} \mathbb{D}$, Dalila Saidane ${ }^{1}$, Ridha Mzoughi ${ }^{1}$ and Fabio Minervini ${ }^{2, *}$ \\ 1 Laboratory of Analysis, Treatment and Evaluation of Environmental Pollutants and Products, Faculty of \\ Pharmacy, Monastir University, 5000 Monastir, Tunisia; missaouijihen@outlook.fr (J.M.); \\ dalila.saidane@fphm.rnu.tn (D.S.); ridha.mzoughi@rns.tn (R.M.) \\ 2 Dipartimento di Scienze del Suolo, della Pianta e degli Alimenti, Università degli Studi di Bari Aldo Moro, \\ 70126 Bari, Italy \\ * Correspondence: fabio.minervini@uniba.it
}

Received: 22 October 2019; Accepted: 15 December 2019; Published: 17 December 2019

\begin{abstract}
Microorganisms inhabiting fermented foods represent the main link between the consumption of this food and human health. Although some fermented food is a reservoir of potentially probiotic microorganisms, several foods are still unexplored. This study aimed at characterizing the probiotic potential of lactic acid bacteria isolated from zgougou, a fermented matrix consisting of a watery mixture of Aleppo pine's seeds. In vitro methods were used to characterize the safety, survival ability in typical conditions of the gastrointestinal tract, and adherence capacity to surfaces, antimicrobial, and antioxidant activities. Strains belonged to the Lactobacillus plantarum group and Enterococcus faecalis showed no DNase, hemolytic, and gelatinase activities. In addition, their susceptibility to most of the tested antibiotics, satisfied some of the safety prerequisites for their potential use as probiotics. All the strains tolerated low $\mathrm{pH}$, gastrointestinal enzymes, and bile salts. They displayed a good antibacterial activity and antibiofilm formation against 10 reference bacterial pathogens, especially when used as a cell-free supernatant. Furthermore, the lactic acid bacteria (LAB) strains inhibited the growth of Aspergillus flavus and Aspergillus carbonarius. Finally, they had good antioxidant activity, although depending on the strain. Overall, the results of this work highlight that zgougou represents an important reservoir of potentially probiotic LAB. Obviously, future studies should be addressed to confirm the health benefits of the LAB strains.
\end{abstract}

Keywords: lactic acid bacteria; Lactobacillus plantarum; Enterococcus faecalis; Pinus halepensis seeds; probiotic traits

\section{Introduction}

Probiotics are live microorganisms that taken in adequate numbers for a given period of time, benefit human and animal health. To provide benefit to health, probiotic microorganisms have to possess some prerequisites, such as resistance to $\mathrm{pH}$ values of the gastrointestinal tract, tolerance to bile salts, and capacity to adhere to intestinal epithelium [1].

Many microorganisms involved in food fermentation have been reported as probiotics, such as Lactobacillus [1,2], Bifidobacterium, Pediococcus [1,3], Lactococcus, Propionibacterium [1,4], Bacillus [1], Enterococcus [5], and some yeasts [6,7]. Those microorganisms were characterized by, besides the above-mentioned prerequisites, antimicrobial activity and the ability to facilitate the growth of gut beneficial microbes [2,8,9]. Lactic acid bacteria (LAB) are ubiquitous microorganisms isolated from fermented food [10,11], grains [12,13], dairy products [14,15], fruits [16,17], honey-comb [18], and soil $[19,20]$. Some LAB shows probiotic traits, having effective benefits on crop and livestock production, 
as well as on human health. In the last decades, many reports have postulated probiotic microorganisms as an adjuvant treatment against gastrointestinal diseases (diarrhea, colon cancer) and skin alterations (photoaging, infections, and cancer) [1,21,22].

Pinus sp. is the largest genus of conifers occurring naturally, especially in the north of the Mediterranean area. These conifers are pioneers and expansionist. Leaves, fruits, and seeds of Pinus sp. are used worldwide in traditional therapeutic practice and have economic importance because of their richness in secondary metabolites and phytochemicals (e.g., turpentine, terpenes, resins, phenolic compounds, essential oils) showing medicinal and aromatic proprieties [23,24]. Pinus halepensis (Aleppo pine) seeds are traditionally used throughout Tunisia and other Arabic countries for preparing a sweet cream pudding called "Assidat-Zgougou", consumed in Tunisia to celebrate the birth of the Prophet MUHAMMED "sallallahu 'alayhi wa sallam". However, currently, the consumption of zgougou also occurs during the rest of the year. The first step of Assidat-Zgougou production is the spontaneous fermentation of a watery mixture of ground Aleppo pine seeds. After fermentation, the mixture, called "zgougou" is subjected to coarse filtration to separate the juice from the seed debris. The juice is added with flour and sugar, and the resulting mixture is baked. Alternatively, seeds of $P$. halepensis are used as an aromatic ingredient in ice-cream and candies $[25,26]$. Secondary metabolites from seeds of $P$. halepensis are used as cosmetics for preventing skin diseases, such as atopic dermatitis, candidiasis, and keratosis, both in healthy and immunocompromised individuals [21]. Anecdotal information is available regarding the benefits to gut from consumption of zgougou. Autochthonous microbes, such as $\mathrm{LAB}$, could be one of the components of zgougou that could benefit human health. However, to our knowledge, nobody thus far isolated and characterized LAB from this spontaneously fermented matrix.

The current study aimed to: (i) Isolate LAB from home-made zgougou; (ii) biotype and identify these LAB; and (iii) explore the potential probiotic capacities of the isolated LAB, as the preliminary basis to exploit them as food supplements (or even medications) for preventing diseases in humans.

\section{Materials and Methods}

\subsection{Isolation of Lactic Acid Bacteria (LAB)}

Fourteen LAB were isolated from spontaneously fermented zgougou, produced using Aleppo pine's seeds collected in the Kasserine region (Tunisia) [27]. In detail, zgougou samples (10 mL) were enriched in $90 \mathrm{~mL}$ of either de Man Rogosa and Sharpe (MRS) (Oxoid, Basingstoke, Hamsphire, UK) or M17 broth (Oxoid). After incubation, under anaerobic conditions at $37^{\circ} \mathrm{C}$ for $24-48 \mathrm{~h}, 100 \mu \mathrm{L}$ of each enrichment broth was spread onto MRS or M17 agar media and incubated under the conditions indicated above. Colonies that showed a positive reaction to Gram coloration, a negative reaction to the catalase test, made of non-motile rods or cocci, and capable of acidifying the broth were randomly picked up and subjected to isolation, through at least 2 consecutive streaks. All the isolates were stored at $-20{ }^{\circ} \mathrm{C}$ in the appropriate broth with $20 \%$ glycerol.

\subsection{Molecular Biotyping and Identification of $L A B$}

The bacterial DNA was extracted using the DNeasy ${ }^{\circledR}$ Blood \& Tissue Kit (250) (Qiagen, Hilden, Germany) according to the manufacturer's instructions. The concentration of extracted DNA was estimated by spectrophotometric determination, using the Nanodrop ND-1000 (Thermo Fisher Scientific Inc, Wilmington, USA). The isolates were biotyped by randomly amplified polymorphic DNA (RAPD)-PCR using 3 primers: M13 (5'-GAGGGTGGCGGTTCT-3') [28], P4 (5'-CCGCAGCGTT-3') and P7 (5'- AGCAGCGTGG-3') [29]. The reaction mixture and PCR conditions for primer M13 were according to reference [30,31]. PCR conditions for primers P4 and P7 were those described by reference [29]. PCR products were separated using the MCE-202 MultiNA microchip electrophoretic system (Shimadzu Italia s.r.l., Milan, Italy), using the DNA-2500 IVD Reagent Kit (Shimadzu) and the pGEM $^{\circledR}$ DNA Marker (Promega Italia, Milano, Italy), according to the manufacturer's instructions. The similarity of the electrophoretic profiles was evaluated by the Pearson product moment correlation 
coefficient (r) and using the unweighted paired group mathematic average algorithm, through Statistica version 12 for Windows.

Bacterial identification was obtained upon partial sequencing of 16S rRNA gene, using the primers LpigF (5'-TACGGGAGGCAGCAGTAG-3') and LpigR (5'-CATGGTGTGACGGGCGGT-3') [32] . $\operatorname{rec} A[33$ ] and pheS [34] genes were partially sequenced in order to discriminate among species belonging to the Lactobacillus plantarum group and Enterococcus sp., respectively. PCR products were purified with illustra GFX PCR DNA and gel band purification kit (GE Healthcare Europe GmbH, Milan, Italy) and sequenced at Eurofins Genomics (Ebersberg, Germany). The DNA sequence homology was determined through pair-wise sequence alignments, using BLAST within the NCBI nucleotide collection database.

\subsection{Probiotic Traits of Lactic Acid Bacteria}

\subsubsection{DNase and Hemolysis Tests}

Ten microliters of bacterial suspension cultured $\left(37^{\circ} \mathrm{C}, 24 \mathrm{~h}\right)$ in MRS or M17 broth were streaked on DNase-mannitol, and Columbia agar media (Oxoid) supplemented with $5 \%(w / v)$ of defibrinated sheep blood (Thermo Fisher Scientific Inc), in order to test the DNase and hemolytic activities, respectively. Plates were anaerobically incubated for $24 / 48 / 72 \mathrm{~h}$ at $37^{\circ} \mathrm{C}$ [34]. DNase activity was indicated by the appearance of a pink halo around the colonies. Staphylococcus aureus ATCC 25923 and Escherichia coli ATCC 35218 were used as positive controls for $\beta$-hemolytic and $\alpha$-hemolytic activities, respectively.

\subsubsection{Antibiotics Susceptibility}

The strains were subjected to a susceptibility test against Ampicillin $(10 \mu \mathrm{g})$, Norfloxacin $(10 \mu \mathrm{g})$, Chloramphenicol $(30 \mu \mathrm{g})$, Erythromycin $(15 \mu \mathrm{g})$, Gentamicin $(10 \mu \mathrm{g})$, Oxytetracyclin $(100 \mu \mathrm{g})$, Streptomycin $(10 \mu \mathrm{g})$, Levofloxacin $(5 \mu \mathrm{g})$, Polymixin B $(50 \mu \mathrm{g})$, Tetracyclin $(30 \mu \mathrm{g})$, Ciprofloxacin

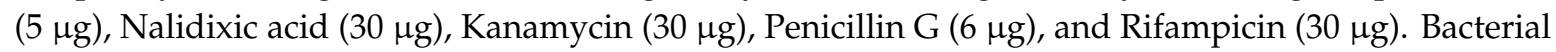
cultures $\left(37^{\circ} \mathrm{C}, 24 \mathrm{~h}\right)$ in MRS or M17 were appropriately diluted with the respective inoculated broth, in order to adjust their absorbance, read (through an Ultrospec 3000 spectrophotometer, GE Healthcare) at a wavelength of $600 \mathrm{~nm}$, to 0.6 U.A., corresponding to $10^{9} \mathrm{CFU} / \mathrm{mL}$. Bacterial suspensions were inoculated on plates of Muller Hinton (MH) agar (Oxoid) using sterile cotton swabs. After having air-dried plates for $15 \mathrm{~min}$, paper discs containing a single antibiotic were lodged on the plates. After $18 \mathrm{~h}$ of incubation at $37^{\circ} \mathrm{C}$, the inhibition zone diameters around each disc were measured. Based on the inhibition zone diameter length, the strains were ranked as resistant $(0 \mathrm{~mm})$, intermediate resistant $(\leq 8 \mathrm{~mm})$, or susceptible ( $\geq 10 \mathrm{~mm}$ ) to antimicrobial substances. Every test was repeated three times.

\subsubsection{Tolerance to Acid, Salt, Pepsin, Pancreatin, and Bile Salt}

Bacterial cultures $\left(37^{\circ} \mathrm{C}, 18-24 \mathrm{~h}\right.$, under anaerobic conditions), were inoculated (initial absorbance of ca. 0.6 U.A., at a wavelength of $600 \mathrm{~nm}$ ) in their respective broths (MRS or M17), adjusted at different $\mathrm{pH}(2.5,3,4$ and 5), or containing different $\mathrm{NaCl}$ concentrations $(w / v)(4,5,8$ and 12\%). After 24 (acid tolerance) and $48 \mathrm{~h}$ (salt tolerance) of incubation, bacterial growth was determined spectrophotometrically $[35,36]$.

Tolerance to pepsin, pancreatin, and bile salt was assessed using bacterial biomass recovered by centrifugation $\left(10,000 \times g, 5 \mathrm{~min}, 4^{\circ} \mathrm{C}\right.$; AVANTI-J25, Beckman Coulter) from overnight cultures. Before the tests, biomass was washed twice with phosphate buffer saline (PBS, $130 \mathrm{mM}$ sodium chloride, $10 \mathrm{mM}$ sodium phosphate; $\mathrm{pH} 7.2)$ and re-suspended in PBS solution $(\mathrm{pH}=2$ and $\mathrm{pH}=3)$ containing pepsin (Sigma-Aldrich, St. Louis, MO, USA) $(3 \mathrm{mg} / \mathrm{mL})$, or PBS solution $(\mathrm{pH}=8)$ containing pancreatin (Sigma-Aldrich) $(1 \mathrm{mg} / \mathrm{mL})$. For assessing the tolerance to bile salt, bacterial biomass was inoculated (initial absorbance of ca. 0.6 U.A., at a wavelength of $600 \mathrm{~nm}$ ) in MRS or M17 broth with $0.3,0.5$, and $0.8 \%(w / v)$ of ox gall bile (Sigma-Aldrich). In all the cases, cell density of LAB was determined by plate counting on MRS or M17 agar media, soon after inoculation $(t=0 \mathrm{~h})$ and after 1 (pepsin only), 
3 (pepsin only), and $4 \mathrm{~h}$ of incubation at $37^{\circ} \mathrm{C}$ (pancreatin and bile salts) [35]. Before plate counting, the bacterial suspensions were serially diluted with sterile physiological solution and $1 \mathrm{~mL}$ of diluted suspensions were inoculated by the pour-plate method. Colonies were counted after $48 \mathrm{~h}$ of anaerobic incubation at $37^{\circ} \mathrm{C}$. Survival rates were expressed as follows:

Survival rates $\%=[$ cell number $(\log \mathrm{CFU} / \mathrm{mL})$ after incubation/ cell number

$(\log \mathrm{CFU} / \mathrm{mL})$ after inoculation] $\times 100$

\subsubsection{Biofilm Production, Adhesion, and Aggregation Capacities}

The crystal violet method was used to determine the potential of the LAB strains to produce a biofilm [37]. In detail, $100 \mu \mathrm{L}$ of overnight liquid cultures were added into the microtiter polystyrene plate wells (Thermo Fisher Scientific Inc) previously coated with $100 \mu \mathrm{L}$ of modified-MRS ( $\%$ glucose) or modified-M17 ( $2 \%$ glucose) broths. The cells were allowed to adhere at $37{ }^{\circ} \mathrm{C}$ for $24 \mathrm{~h}$. After incubation, the non-adherent cells were removed by washing the wells 3 times with $200 \mu \mathrm{L}$ of PBS. The adhered cells were stained with crystal violet (Sigma-Aldrich) $(100 \mu \mathrm{L} /$ well, $0.1 \%, w / v$, solution) for 30 $\mathrm{min}$. Wells were subsequently washed 5 times with PBS to remove the excess stain. After $30 \mathrm{~min}$ of incubation at room temperature, the absorbance at $640 \mathrm{~nm}$ was determined using a microtiter plate reader (Biochrom Asys Expert Plus microplate reader, UK). Wells containing non-inoculated broth were used as a negative control. Results were expressed by subtracting the absorbance value of this negative control from the absorbance value recorded for each inoculated well. Each experiment was performed in triplicate [38].

Congo Red (CR) (Oxoid) binding assay was used to assess the adhesion capacity of LAB. One hundred microliters of overnight liquid culture were streaked on MRS agar supplemented (after sterilization) with CR $(0.01 \%, w / v)$. After incubation $\left(37^{\circ} \mathrm{C}\right.$ for $\left.48-72 \mathrm{~h}\right)$, plates were examined, and the intense red colonies were considered as CR-bound cells [39].

The auto-aggregation activity of LAB was assessed using bacterial biomass recovered by centrifugation $\left(5,000 \times g, 15 \mathrm{~min}, 4^{\circ} \mathrm{C}\right)$ from overnight cultures. Biomass was washed twice end re-suspended in PBS and adjusted to ca. $10^{9} \mathrm{CFU} / \mathrm{mL}$, using spectrophotometric determination. Cell suspensions $(4 \mathrm{~mL})$ were mixed vigorously, and then auto-aggregation was checked during $5 \mathrm{~h}$ of incubation at ambient temperature. Every hour, the absorbance (at $600 \mathrm{~nm}$ ) of a mixture of the upper suspension $(100 \mu \mathrm{L})$ and PBS $(3.9 \mathrm{~mL})$ was determined [40]. The auto-aggregation potential was calculated as follows:

$$
\mathrm{AA} \%=1-(\mathrm{At} / \mathrm{A} 0) \times 100
$$

where $A_{t}$ represents the absorbance after $1,2,3,4$, or $5 \mathrm{~h}$, and $A_{0}$ represents the absorbance at $t=0$.

\subsubsection{Cell Surface Hydrophobicity Test}

The degree of hydrophobicity of LAB was determined by estimating cellular adhesion to hydrocarbons [36]. Liquid cultures $\left(24 \mathrm{~h}, 37^{\circ} \mathrm{C}\right.$, anaerobic conditions) of LAB were centrifuged $(6000 \times g, 5 \mathrm{~min})$, and the pellets were washed twice and re-suspended in Ringer Solution $(6 \% \mathrm{NaCl}$, $0.00075 \% \mathrm{KCl}, 0.01 \% \mathrm{CaCl}_{2}$ and $0.01 \% \mathrm{NaHCO}_{3}$ ). The absorbance was measured at $600 \mathrm{~nm}$ (reading 1 ). Then $1.5 \mathrm{~mL}$ of the cell suspension was mixed with an equal volume of chloroform (Sigma-Aldrich), ethyl acetate (Sigma-Aldrich), or n-hexadecane (Sigma-Aldrich), and incubated for $30 \mathrm{~min}$ at room temperature. After incubation, the absorbance of $1 \mathrm{~mL}$ carefully collected from the upper phase of suspension was determined (reading 2). The hydrophobicity activity was calculated using the following equation:

Hydrophobicity $\%=[[\mathrm{A} 600 \mathrm{~nm}($ reading 1) $-\mathrm{A} 600 \mathrm{~nm}$ (reading 2) $] / \mathrm{A} 600 \mathrm{~nm}($ reading 1) $] \times 100$ 


\subsubsection{Enzyme Activities}

Extracellular amylase, protease, and lipase activities of the LAB strains were qualitatively determined, according to the method described by Maria et al., 2005 [41]. For amylase and protease, soluble starch (Sigma-Aldrich) (2\%, final concentration) and gelatin (Sigma-Aldrich) $(0.4 \%$, final concentration) was added to MRS or M17 agar, respectively. For the gelatinase test, S. aureus ATCC 25923 and E. coli ATCC 35218 were used as positive and negative controls, respectively. Extracellular esterase was measured as well, according to the method described by Carrim et al., 2006 [42]. For the lipase and esterase, Tween 20 (Sigma-Aldrich) (1\%) and Tween 80 (Sigma-Aldrich) (1\%) were added to the peptone agar medium (Himedia, Mumbai, India), respectively. $10 \mu \mathrm{L}$ of bacterial suspension cultured overnight in MRS or M17 broth were adsorbed on Whatman discs ( $3 \mathrm{~mm}$ diameter). Inoculated discs were lodged on plates containing media with soluble starch, gelatin, Tween 20, or Tween 80 . After incubation $\left(37^{\circ} \mathrm{C}, 24-48 \mathrm{~h}\right)$, plates were examined and the presence of a clear halo around the disc indicated the presence of enzyme activity.

\subsubsection{Antimicrobial Activity}

The antibacterial activity of LAB strains was tested against the following target microorganisms grown in nutrient broth (NB) (Oxoid) at $37{ }^{\circ} \mathrm{C}$ for $24 \mathrm{~h}$ : Staphylococcus aureus ATCC 25923, Staphylococcus epidermidis CIP 106510, Micrococcus luteus NCIMB 8166, Escherichia coli ATCC 35218, Listeria monocytogenes ATCC 19115, Pseudomonas aeruginosa ATCC 27853, Enterococcus faecalis ATCC 29212, Salmonella Typhimurium ATCC 1408, Bacillus cereus ATCC 11778, and Vibrio parahaemolyticus ATCC 17802. Before the test, the spent broth recovered from $24 \mathrm{~h}$-old LAB cultures was neutralized by $1 \mathrm{M} \mathrm{NaOH}$ and represented the cell-free supernatant (CFS). Plates of $\mathrm{MH}$ agar were singly inoculated, through spread technique, with $100 \mu \mathrm{L}$ of liquid culture of target microorganisms. The CFS was loaded in wells of $5 \mathrm{~mm}$ diameter. After $60 \mathrm{~min}$ of incubation at $4{ }^{\circ} \mathrm{C}$, plates were transferred into an incubator set at $37^{\circ} \mathrm{C}$. After $24-48 \mathrm{~h}$ of incubation, the antibacterial activity of each CFS was expressed by measuring the diameter of the inhibition zone (clear zone) around the well [43]. Each CFS was tested in triplicate.

The minimum inhibitory concentration (MIC) of the CFS from LAB was evaluated by filling 96 well polystyrene microplates (NUNC ${ }^{\mathrm{TM}}$, Denmark) with different dilutions of CFS and MH broth singly inoculated with target microorganisms [43]. The inhibitory effect was rated by measuring the ability of the target microorganism to grow in the presence of the CFS, spectrophotometrically at 600 $\mathrm{nm}$. The test was performed in triplicate. The MIC value was the lowest concentration of CFS that did not allow the growth of the target microorganism. The minimum bactericidal concentration (MBC) was assessed by inoculating, on $\mathrm{MH}$ agar, $10 \mu \mathrm{L}$ from the well containing bacterial suspension that had not grown after microplate incubation. After incubation $\left(37^{\circ} \mathrm{C}, 24 \mathrm{~h}\right)$, plates were inspected for bacterial growth and $\mathrm{MBC}$ was defined as the lowest concentration of CFS showing bactericidal activity.

A dual culture technique was used for determining inhibitory activity of LAB strains against Aspergillus carbonarius and Aspergillus flavus [44]. Before the assay, fungal conidia were harvested and cultured for 7 days at $28^{\circ} \mathrm{C}$ on Potato Dextrose Agar (PDA, Oxoid). Then, the surface of the PDA plate was washed with $5 \mathrm{~mL}$ of sterile peptone water $(0.1 \%)$ (Himedia) mixed with one drop of Tween 80 (Sigma-Aldrich). The resulting mixture of sporangiospores and hyphal fragments was filter-sterilized and transferred to a sterile tube to separate conidia from hyphal fragments [44]. $10 \mu \mathrm{L}$ of each LAB strain, cultured overnight at $37^{\circ} \mathrm{C}$ in MRS or M17 broth, was streaked across the center of MRS or M17 agar plate. $10 \mu \mathrm{L}$ of fungal suspension of $\left(10^{6}\right.$ spores $\left./ \mathrm{mL}\right)$ was placed at the side $(2.5 \mathrm{~cm}$ far) of the LAB streak. One control plate, containing just the fungal inoculum, was also prepared. Plates were then incubated at $37^{\circ} \mathrm{C}$ for 7 days. Mycelial growth was measured when mycelium in the control plate was fully developed, and the antifungal activity was expressed as follows:

$$
\mathrm{GI} \%=(\mathrm{R} 1-\mathrm{R} 2) / \mathrm{R} 1 \times 100
$$


where GI\% represents the percentage of fungal growth inhibition, $\mathrm{R} 1$ is the farthest radial distance (measured in $\mathrm{mm}$ ) from the tested LAB streak, reached by the fungal colony, and R2 is the distance from the point of fungal inoculation to the tested LAB streak, namely $2.5 \mathrm{~cm}$. GI was categorized on a scale from 0 to 4 , where $0=$ no GI, $1=1 \%$ to $25 \%$ GI, $2=26 \%$ to $50 \%$ GI $3=51 \%$ to $75 \%$ GI and $4=76 \%$ to $100 \%$ GI $[45,46]$.

In addition, another method was used for determining the antifungal activity of CFS of each strain [47]. In order to qualitatively evaluate the chemical nature of the possible antifungal compounds present in each CFS, CFS, obtained as described above, was subjected to $\mathrm{pH}$ adjustment ( $\mathrm{pH} 6.5$ with $46 \%, w / v, \mathrm{NaOH}$ aqueous solution) and added $(10 \%, v / v)$ to Sabouraud Dextrose (SD) Agar (Oxoid) ( $\mathrm{pH} 4)$ inside a petri dish $(20 \mathrm{~mL} /$ plate). The plate was centrally inoculated with $10 \mu \mathrm{L}$ of the sporal suspension (prepared as described above) and incubated at $25^{\circ} \mathrm{C}$. Control plates containing SD agar and $10 \%(v / v)$ SD broth were also prepared and inoculated with a fungal spore suspension. After a 4 to 7 days incubation period (depending on the required time by each mold to grow and fill the control plate), the area of mycelial growth in both treated (AT) and control (AC) plates was calculated using the averaged diameter, assuming a circular growth. The percentage of growth inhibition (I) was calculated as follows:

$$
\mathrm{I}=100 \times(\mathrm{AC}-\mathrm{AT} / \mathrm{AC})
$$

Antifungal activity was quantified by broth microdilution assay according to the National Committee for Clinical Laboratory Standards $[47,48]$ with slight modifications. Microdilution assays were performed with a 96-well sterile microtiter plate. The CFS was dispatched, as such or diluted, into each well $(180 \mu \mathrm{L})$. Then, $2 \mu \mathrm{L}$ of fungal spore suspension was added at a final concentration of $10^{5}$ spores/mL. Subsequently, the fungal growth was visually examined after $48 \mathrm{~h}$ of incubation at $25^{\circ} \mathrm{C}$. MIC was considered as the highest dilution of the CFS capable of inhibiting fungi [48]. The fungicidal activity of each CFS was evaluated on the suspension containing the dilution level that did not show visible fungal growth. $100 \mu \mathrm{L}$ were taken from the well and spotted onto the MRS and M17 agar plates. After incubation at $37^{\circ} \mathrm{C}$ for $48 \mathrm{~h}$, plates were examined for fungal growth. The highest dilution of the CFS with fungicidal activity was defined as the minimum fungicidal concentration (MFC).

\subsubsection{Inhibition of Biofilm Production}

The ability of LAB strain to inhibit biofilm production was estimated according to the method described previously [39]. In detail, the reduction, by metabolically active cells of XTT (2, 3-bis (2-methyloxy-4-nitro-5-sulfophenyl)-2H-tetrazolium-5-carboxanilide) (Sigma-Aldrich), a tetrazolium salt, to a colored formazan was quantified colorimetrically. LAB cells or LAB CFS (absorbance of 0.6 U.A. at $600 \mathrm{~nm}$ ) were co-inoculated with target pathogenic bacteria (grown in NB, at $37^{\circ} \mathrm{C}$ for $18-24 \mathrm{~h}$; absorbance of 0.3 U.A. at $600 \mathrm{~nm}$ ) in 96-well polystyrene microplates containing brain heart infusion (BHI) (Oxoid) broth with $2 \%$ glucose $(w / v)$. Negative control wells contained just BHI with glucose, whereas positive control wells contained BHI with glucose, inoculated with pathogenic bacteria. XTT solution $(1 \mathrm{mg} / \mathrm{mL})$ was prepared in PBS and filtered-sterilized and menadione (Sigma-Aldrich) solution $(0.4 \mathrm{mM})$ was prepared in acetone and filtered-sterilized immediately before each assay. After incubation $\left(24-48 \mathrm{~h}, 37^{\circ} \mathrm{C}\right)$, the biofilms were firstly washed 5 times with PBS, and then $180 \mu \mathrm{L}$ PBS and $20 \mu \mathrm{L}$ of XTT-menadione solution $(12.5: 1 \mathrm{v} / \mathrm{v})$ were added to each of the wells. The microplate was then incubated for $3 \mathrm{~h}$ in the dark at $37^{\circ} \mathrm{C}$. After incubation, the color change in the suspension was measured through a Multiskan FC Microplate Photometer (Thermo Fisher Scientific Inc) set at a wavelength of $492 \mathrm{~nm}$.

The percentage of inhibition of biofilm production was calculated using the equation:

$$
\text { [(A growth control }- \text { A sample)/A growth control] } \times 100
$$

where "a growth control" is the absorbance of the well containing the positive control, and "a sample" is the absorbance of the wells containing the tested LAB strain. Each assay was repeated 3 times. 


\subsubsection{Antioxidant Activity}

The antioxidant activity of the LAB strains was assayed through 3 methods: Radical scavenging activity, $\beta$-carotene bleaching assay, and reducing power antioxidant activity. Before assays, bacterial strains were prepared as follows. After having cultured $\left(24 \mathrm{~h}\right.$ at $\left.37^{\circ} \mathrm{C}\right)$ each LAB strain, bacterial cells were collected by centrifugation $\left(8000 \times g, 10 \mathrm{~min}, 4^{\circ} \mathrm{C}\right)$. Afterward, the CFS from each bacterial strain was recuperated and filtered by a sterile filter $(0.22 \mu \mathrm{m})$, whereas the cell pellets were re-suspended in sterile distilled water. For radical scavenging activity, 2,2-DiPhenyl-1-PicrylHydrazyl (DPPH) (Sigma-Aldrich) was used and the test was carried out according to the method of Ali Bougataf et al. [49]. In detail, $167 \mu \mathrm{L}$ of each test sample were mixed with $167 \mu \mathrm{L}$ of DPPH $(2.5 \mathrm{~g} / \mathrm{L})$ and $667 \mu \mathrm{L}$ of methanol $(80 \%, v / v)$. The reaction mixture was incubated in the dark up to $120 \mathrm{~min}$ at $25^{\circ} \mathrm{C}$. The absorbance of the reaction mixture was measured at $517 \mathrm{~nm}$ at $0,10,20,30,60$, and $120 \mathrm{~min}$. Two positive controls were used: Butyl hydroxytoluene (BHT) (Sigma-Aldrich) $(0.45 \mathrm{~g} / \mathrm{L}$ in methanol $80 \%)$ and ascorbic acid (1\%). A reaction mixture consisting just of $167 \mu \mathrm{L}$ of DPPH and $833 \mu \mathrm{L}$ of methanol (80\%) was always inserted as the blank. The radical scavenging activity was calculated as follows:

$$
\text { DPPH radical-scavenging activity }(\%)=\left[\left(\mathrm{A}_{\text {blank }}-\mathrm{A}_{\text {sample }}\right) / \mathrm{A}_{\text {blank }}\right] \times 100
$$

where $A_{\text {blank }}$ is the absorbance (at $517 \mathrm{~nm}$ ) of the reaction mixture containing all reagents without the LAB cells or CFS, and $A_{\text {sample }}$ is the absorbance in the presence of the LAB cells or CFS.

The $\beta$-carotene bleaching assay was performed according to Trabelsi et al. [50], with slight modifications. In detail, $1 \mathrm{mg}$ of $\beta$-carotene (Sigma-Aldrich) was dissolved in $5 \mathrm{~mL}$ of chloroform; then $25 \mathrm{~mL}$ of linoleic acid (Sigma-Aldrich) and $200 \mathrm{mg}$ of Tween 40 (Sigma-Aldrich) were added. Chloroform was evaporated by treating the sample at $40{ }^{\circ} \mathrm{C}$ in a vacuum centrifuge (SpeedVac Concentrator SPD121P, Thermo Scientific). Then, $50 \mathrm{~mL}$ of demineralized water was added, and the mixture was vigorously shaken. The emulsion obtained was freshly prepared before each experiment. $2.5 \mathrm{~mL}$ of the $\beta$-carotene: Linoleic acid emulsion was mixed with an equal volume of the test samples that were prepared in the same way described previously for the DPPH assay. An equal amount of methanol $80 \%$ was used for the blank sample. BHT $(0.1 \%$ in methanol $80 \%)$ was used as a positive control. Three replicates were prepared for each of the samples. Readings of all samples were performed spectrophotometrically at $470 \mathrm{~nm}$ immediately $(\mathrm{t}=0 \mathrm{~min})$, and after 6,24 and $48 \mathrm{~h}$.

The results were expressed as percentage of antioxidant activity (AA\%), using this equation:

$$
\mathrm{AA} \%=[1-[(\mathrm{A} 0 \text { sample-An sample }) /(\mathrm{A} 0 \text { control-An control })]] \times 100
$$

where " $\mathrm{A}_{0}$ sample" is the absorbance at $470 \mathrm{~nm}$ at the start of the reaction, "An sample" is the absorbance after 6,24 , or $48 \mathrm{~h}$, " $\mathrm{A}_{0}$ control" is the absorbance of a mixture not containing $\mathrm{LAB}$ (control), and " $A_{n}$ control" is the absorbance of the control after 6, 24, or $48 \mathrm{~h}$.

The reducing power activity of LAB strains was determined according to the method of Sung Ho-son et al. [51]. The mixture, containing $200 \mu \mathrm{L}$ of LAB cell suspension or CFS, $200 \mu \mathrm{L}$ of $0.2 \mathrm{M}$ sodium phosphate buffer ( $\mathrm{pH}$ 6.6) and $200 \mu \mathrm{L}$ of $1 \%$ potassium ferricyanide (Sigma-Aldrich), was incubated at $50{ }^{\circ} \mathrm{C}$ for $20 \mathrm{~min}$. Then, $0.2 \mathrm{~mL}$ of trichloroacetic acid $(10 \%, w / v)$ was added, and the mixture was centrifuged $\left(8000 \times g, 10 \mathrm{~min}, 4^{\circ} \mathrm{C}\right)$. Then, $500 \mu \mathrm{L}$ of the supernatant was collected and mixed with $100 \mu \mathrm{L}$ of $0.1 \%$ ferric chloride (Sigma-Aldrich) and $400 \mu \mathrm{L}$ of distilled water and left to react for $10 \mathrm{~min}$. The absorbance reading of the samples was measured at $700 \mathrm{~nm}$, and L-cysteine (Sigma-Aldrich) was used as a positive control.

\subsection{Statistical Analyses}

The experimental data obtained were expressed as means \pm SD. For all experiments, the differences between the control and treated groups were analyzed by STUDENT TEST, using XLSTAT 2018. 


\section{Results}

\subsection{Safety of Lactic Acid Bacteria (LAB) Strains Identified from Zgougou}

The LAB isolated from zgougou showed different RAPD-PCR profiles (Supplementary Figures S1-S3). The dendrogram built upon the combination of the profiles (Figure 1) showed that the linkage distance between isolates varied from ca. 0.35 (isolates A6 and A14) to ca. 0.90 (isolates A1 and A3). Therefore, all the isolates were subjected to molecular identification. Two strains (A2 and A3, from MRS plates) were allotted to Lactobacillus plantarum, one strain (A1, from MRS) to Lactobacillus paraplantarum and all the other strains (A4-A14, from M17 plates) to Enterococcus faecalis.

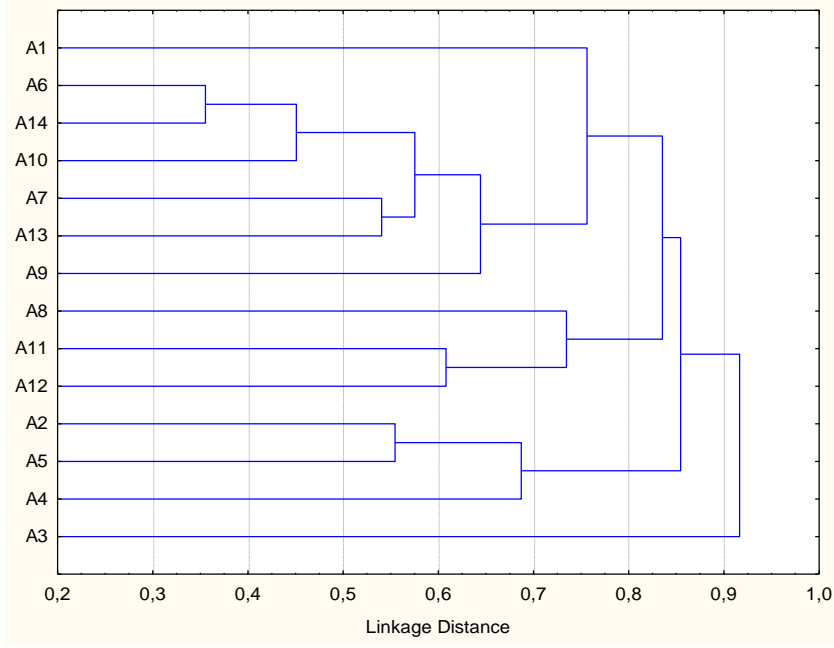

Figure 1. Dendrogram obtained by combined randomly amplified polymorphic DNA-polymerase chain reaction (RAPD-PCR) patterns of the isolates from fermented zgougou. Primers M13, P4, and P7 were used for RAPD-PCR analysis. Cluster analysis was based on the Pearson moment correlation coefficient (r) and unweighted pair grouped method with arithmetic average.

No LAB showed DNAse and $\alpha$ - or $\beta$-hemolytic activity (data not shown). All the LAB strains were susceptible to chloramphenicol, levofloxacin, penicillin $\mathrm{G}$ (except for E. faecalis A11), polimixin B sulfate, rifampicin and tetracyclin (Table S1). Resistance to kanamycin and oxytetracyclin was found for almost all the strains. The remaining 7 antibiotics showed different activity depending on the species and strain. Strains of the L. plantarum group were resistant to streptomycin, norfloxacin, and ciprofloxacin, whereas all the enterococci strains were inhibited by these three anitbiotics. E. faecalis A6, A7, A10, A12, and A14 were susceptible to 13 out of 15 antibiotics.

\subsection{Tolerance to Stressing Environmental Conditions}

All the LAB strains showed good tolerance to the lowest $\mathrm{NaCl}$ concentration, their survival rate ranging from ca. 54\% (E. faecalis A4, A5, A6, and A12) to 84\% (E. faecalis A11) (Figure 2). Overall, all of them were susceptible to $\mathrm{NaCl}$ concentrations of $8 \%$ and $12 \%$. However, among them, L. paraplantarum A1 showed the highest survival rates (37\%) even after exposure to relatively high $\mathrm{NaCl}$ concentrations.

All the selected strains exhibited high tolerance after $24 \mathrm{~h}$ of incubation in growth media adjusted at $\mathrm{pH} 4$ or 5 , the survival rate ranging from $60 \%$ (E. faecalis A4) to $96 \%$ (E. faecalis A6) (Figure 3). LAB grown at $\mathrm{pH} 3$ showed different survival rates depending on the strain. For instance, within strains of E. faecalis, survival rate ranged from ca. 40\% (A5) to 90\% (A6). Despite being grown at pH 2.5, L. plantarum A2, and E. faecalis A6, A8, A11, and A13 showed relatively high survival rates (from approximately $50 \%$ to $75 \%$ ). 


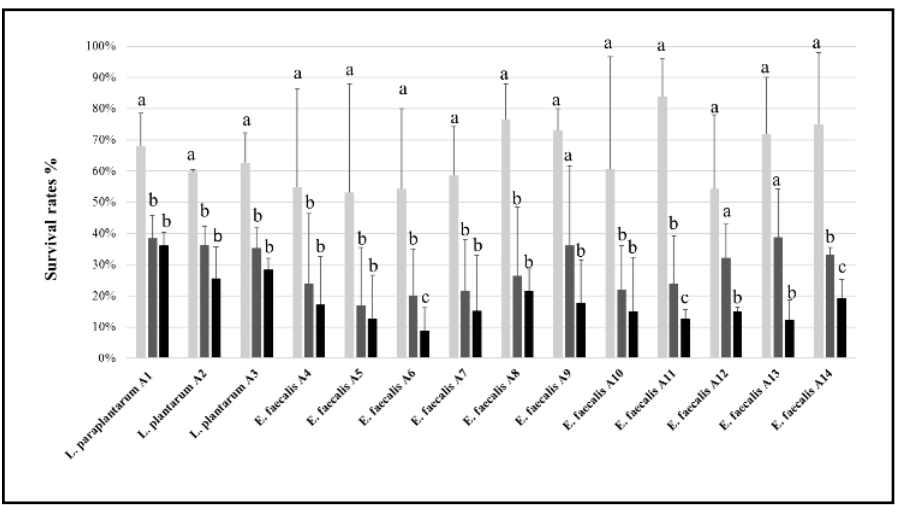

Figure 2. Survival rates (\%) of the lactic acid bacteria (LAB) strains grown at $37^{\circ} \mathrm{C}$ for $48 \mathrm{~h}$ in MRS or M17 media containing $\mathrm{NaCl}$, at a concentration of $4 \%$ (light grey bars), $8 \%$ (dark grey bars), or $12 \%$ (black bars). For each strain, the bars sharing one common letter $(\mathrm{a}-\mathrm{c})$ indicate not significantly $(p>0.05)$ different values of survival rate.

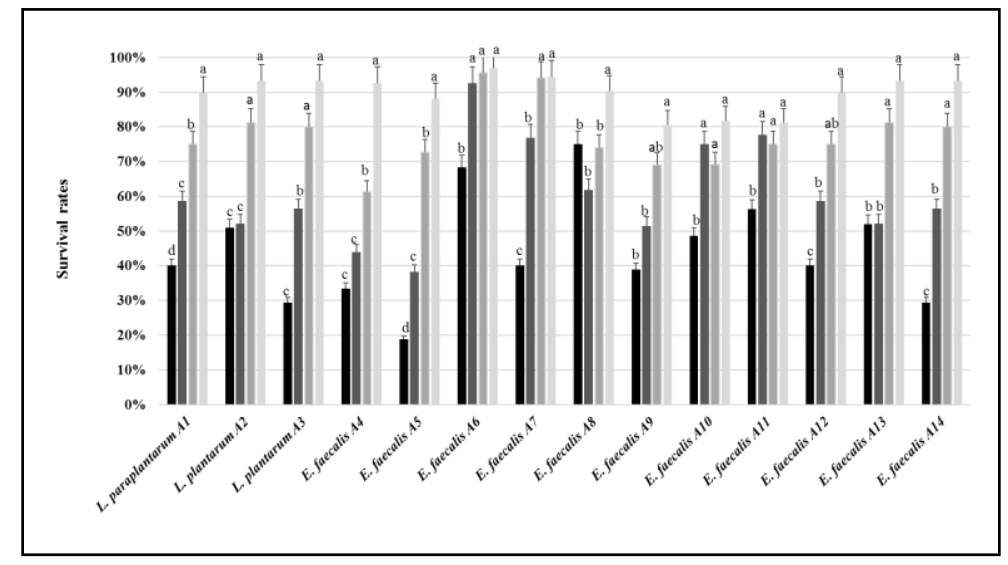

Figure 3. Survival rates (\%) of the LAB strains grown at $37^{\circ} \mathrm{C}$ for $24 \mathrm{~h}$ in MRS or M17 media adjusted at pH 2.5 (black bars), 3 (dark grey), 4 (grey), or 5 (light grey). For each strain, the bars sharing one common letter $(\mathrm{a}-\mathrm{d})$ indicate not significantly $(p>0.05)$ different values of survival rate.

The tested LAB showed different tolerance to pepsin after 1-3 h of exposure (Table S2). The strains belonging to the L. plantarum group (A1, A2, A3) and the strains A4, A7, and A14, allotted to E. faecalis, were the most tolerant after $3 \mathrm{~h}$ of treatment with pepsin at $\mathrm{pH} 2$, with survival rates ranging from $60 \%$ (E. faecalis A7) to 77\% (L. paraplantarum A1). After $3 \mathrm{~h}$ of exposure with pepsin at $\mathrm{pH}$, all the strains were more tolerant than in the treatment at lower $\mathrm{pH}$, showing survival rates between ca. $48 \%$ (E. faecalis A5 and A11) and 79\% (E. faecalis A8). Overall, strains of E. faecalis showed higher survival rates after $4 \mathrm{~h}$ exposure to pancreatin, compared to lactobacilli strains (Table S2).

All the LAB strains could tolerate the exposure to 1\% bile salts A5 (Figure 4), being E. faecalis A4 and A11 the two most tolerant strains, showing survival rates of ca. 90\%. E. faecalis A12 was the most susceptible strain to bile salts (survival rate of ca. 30\%). Similar results were found when LAB strains were exposed to lower concentrations of bile salts (data not shown). 




Figure 4. Survival rates (\%) of the LAB strains exposed for 0 (light grey bars), and 4 (black bars) h to $1 \%$ bile salt. For each strain, the bars sharing one common letter $(a-b)$ indicate not significantly $(p>0.05)$ different values of survival rate.

\subsection{Biofilm Production, Adhesion and Aggregation Capacities}

E. faecalis A6 and A7 were characterized by the highest capacity to produce biofilm (Figure 5). The lowest capacity (absorbance values lower than 1) was found for E. faecalis A8, A9, A10, and A11, whereas the remaining strains had the intermediate capacity. L. paraplantarum $\mathrm{A} 1$, L. plantarum $\mathrm{A} 2$, E. faecalis A4, A5, A6, A7, A12, A13, and A14 showed high adhesion capacity (data not shown). All the strains had a very high capacity of auto-aggregation, ranging from $92 \%$ to $98 \%$ (data not shown).

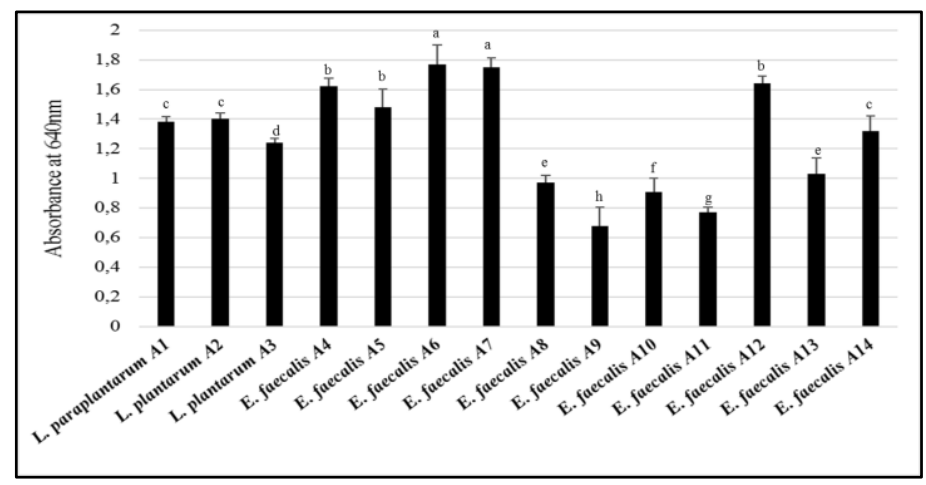

Figure 5. The capacity of producing biofilm by the LAB strains, expressed in terms of absorbance at $640 \mathrm{~nm}$ of crystal violet. The bars sharing one common letter $(\mathrm{a}-\mathrm{h})$ indicate not significantly $(p>0.05)$ different values of biofilm production capacity.

\subsection{Cell Surface Hydrophobicity Test}

The hydrophobicity, tested using n-hexadecane, ranged between ca. 55\% (E. faecalis A6) and 90\% (L. paraplantarum A1, L. plantarum A2, E. faecalis A12 and A13), whereas when chloroform was used in the test, the hydrophobicity varied from ca. 46\% (E. faecalis A10) to 73\% (E. faecalis A5 and A9) (Table 1). Overall, lower values of hydrophobicity were found when ethyl acetate was used, ranging between ca. $8 \%$ (E. faecalis A9) and 66\% (L. plantarum A2 and E. faecalis A13). All the strains were regarded as highly hydrophobic, at least towards one of the three compounds used in testing. The only exception was for E. faecalis A4, which was ranked as having intermediate hydrophobicity. 
Table 1. Percentage * of cell surface hydrophobicity of the LAB strains towards n-hexadecane, chloroform, or ethyl acetate.

\begin{tabular}{llll}
\hline LAB Strain & n-Hexadecane & Chloroform & Ethyl Acetate \\
\hline L. paraplantarum A1 & $90 \pm 0.4^{\mathrm{a}}\left(\mathrm{H}^{\S}\right)$ & $53 \pm 0.2^{\mathrm{bc}}\left(\mathrm{M}^{\S}\right)$ & $64 \pm 0.2^{\mathrm{a}}(\mathrm{M})$ \\
L. plantarum A2 & $90 \pm 0.4^{\mathrm{a}}(\mathrm{H})$ & $70 \pm 0.5^{\mathrm{a}}(\mathrm{H})$ & $66 \pm 0.0^{\mathrm{a}}(\mathrm{M})$ \\
L. plantarum A3 & $79 \pm 0.5^{\mathrm{b}}(\mathrm{H})$ & $70 \pm 1.2^{\mathrm{a}}(\mathrm{H})$ & $24 \pm 2.1^{\mathrm{c}}(\mathrm{M})$ \\
E. faecalis A4 & $64 \pm 1.2^{\mathrm{b}}(\mathrm{M})$ & $66 \pm 1.2^{\mathrm{ab}}(\mathrm{M})$ & $39 \pm 0.6^{\mathrm{bc}}(\mathrm{M})$ \\
E. faecalis A5 & $55 \pm 1.3^{\mathrm{c}}(\mathrm{M})$ & $73 \pm 0.6^{\mathrm{a}}(\mathrm{H})$ & $51 \pm 1.2^{\mathrm{a}}(\mathrm{M})$ \\
E. faecalis A6 & $75 \pm 0.6^{\mathrm{b}}(\mathrm{H})$ & $65 \pm 0.9^{\mathrm{ab}}(\mathrm{M})$ & $35 \pm 0.3^{\mathrm{bc}}(\mathrm{L})$ \\
E. faecalis A7 & $83 \pm 0.5^{\mathrm{ab}}(\mathrm{H})$ & $71 \pm 0.8^{\mathrm{a}}(\mathrm{H})$ & $21 \pm 2.7^{\mathrm{c}}(\mathrm{L})$ \\
E. faecalis A8 & $78 \pm 1.2^{\mathrm{b}}(\mathrm{H})$ & $61 \pm 0.3^{\mathrm{b}}(\mathrm{M})$ & $24 \pm 0.6^{\mathrm{c}}(\mathrm{L})$ \\
E. faecalis A9 & $75 \pm 0.9^{\mathrm{b}}(\mathrm{H})$ & $73 \pm 0.7^{\mathrm{a}}(\mathrm{H})$ & $8 \pm 0.8^{\mathrm{d}}(\mathrm{L})$ \\
E. faecalis A10 & $85 \pm 0.3^{\mathrm{ab}}(\mathrm{H})$ & $46 \pm 0.2^{\mathrm{c}}(\mathrm{M})$ & $22 \pm 0.4^{\mathrm{c}}(\mathrm{L})$ \\
E. faecalis A11 & $77 \pm 0.5^{\mathrm{b}}(\mathrm{H})$ & $59 \pm 1.0^{\mathrm{bc}}(\mathrm{M})$ & $46 \pm 0.4^{\mathrm{b}}(\mathrm{M})$ \\
E. faecalis A12 & $90 \pm 0.4^{\mathrm{a}}(\mathrm{H})$ & $53 \pm 0.2^{\mathrm{bc}}(\mathrm{M})$ & $64 \pm 0.2^{\mathrm{a}}(\mathrm{M})$ \\
E. faecalis A13 & $90 \pm 0.4^{\mathrm{a}}(\mathrm{H})$ & $71 \pm 0.5^{\mathrm{a}}(\mathrm{H})$ & $66 \pm 0.0^{\mathrm{a}}(\mathrm{M})$ \\
E. faecalis A14 & $79 \pm 0.5^{\mathrm{b}}(\mathrm{H})$ & $70 \pm 1.2^{\mathrm{a}}(\mathrm{H})$ & $24 \pm 2.1^{\mathrm{c}}(\mathrm{M})$
\end{tabular}

*Values in the same column with at least one common letter $(\mathrm{a}-\mathrm{d})$ showed no significant $(p>0.05)$ differences. $\mathrm{H}^{\S}$, highly hydrophobic (71-100\%); M, intermediately hydrophobic (36-70\%); L, lowly hydrophobic (0-35\%), according to Thalpa $\mathrm{N}$ et al. 2004 [36].

\subsection{Enzyme Activities}

None of the tested strains exerted gelatinase activity. E. faecalis A5, A7, A9, A11, A12, and A13 showed the highest lipase activity, with a halo diameter longer than $10 \mathrm{~mm}$ (data not shown). All the other strains had lower lipase activity (halo diameter ranging from 4 to $10 \mathrm{~mm}$ ). High esterase activity was found for four strains (E. faecalis A4, A8, A11, and A14). The remaining strains showed lower levels of esterase. All the strains displayed high amylase activity, with the exception of L. plantarum A2 and $\mathrm{A} 3$, and E. faecalis A4 (data not shown).

\subsection{Antibacterial Activity}

All the LAB strains inhibited at least 7 out of 10 target bacteria (Table S3). Six strains (E. faecalis A5, A7, A8, A9, A10, and A12) inhibited all the target bacteria. The pathogenic indicator E. faecalis ATCC 29212 was inhibited by all the LAB strains, including those belonging to the same species. $M$. luteus and E. coli were especially inhibited by the strains of the L. plantarum group. S. Typhimurium, $B$. cereus, and $V$. parahaemolyticus could hardly be inhibited by only some of the tested LAB. MIC values of CFS of the tested LAB ranged between ca. $2.5 \times 10^{8}$ and $4.5 \times 10^{8} \mathrm{CFU} / \mathrm{mL}$. Bactericidal activity of the CFS ranged from $2.5 \times 10^{8}$ to $5.0 \times 10^{8} \mathrm{CFU} / \mathrm{mL}$. All the CFS from strains belonging to E. faecalis had no bactericidal activity towards all the target bacteria, with the exception of S. aureus, S. epidermidis, $M$. luteus, and E. faecalis (data not shown).

The LAB strains could inhibit biofilm formation by the pathogenic bacteria, with a percentage ranging from ca. 31\% to $89 \%$ (Table S4). Among the most active strains, E. faecalis A5 showed inhibitory activity against biofilm formed by S. epidermidis, S. aureus, M. luteus, P. aeruginosa, or E. faecalis. Biofilm production by S. aureus was strongly inhibited by E. faecalis A12. E. faecalis A6 and A7 were the most active biofilm inhibitors against P. aeruginosa and E. coli, respectively. E. faecalis A4 and A13 strongly inhibited biofilm formation by the pathogenic bacteria E. faecalis and S. Typhimurium, respectively.

\subsection{Antifungal Activity}

The LAB strains displayed antagonistic activity against Aspergillus flavus and Aspergillus carbonarius (Table 2). A. flavus was inhibited by the cell pellets, with values ranging from ca. $50 \%$ (L. paraplantarum A1 and L. plantarum A3) to 71\% (E. faecalis A13). The inhibitory activity of the cells of LAB strains against $A$. carbonarius varied from ca. $59 \%$ (E. faecalis A14) to $97 \%$ (L. paraplantarum A1). The results obtained using the CFS from LAB were in good agreement with those obtained using cells. However, 
the CFS from the strains A1, A2 and A3, belonging to the L. plantarum group, were characterized by the lowest inhibitory activity against both fungal species. Overall, A. carbonarius was more sensitive to LAB cells or CFS than A. flavus. MIC values varied from $40 \%$ (L. plantarum A2) to 80\% (E. faecalis A12), and from $50 \%$ (strains of the L. plantarum group) to 70\% (E. faecalis A8, A9, A10, and A11) against $A$. flavus and A. carbonarius, respectively (data not shown). Results on MFC showed that the LAB strains produced compounds that inactivated the two target fungi.

Table 2. Antifungal activity * of LAB strains expressed as percentage of mycelial growth inhibition (GI\%) caused by the cells or as percentage of inhibition (I\%) caused by the cell-free supernatant (CFS).

\begin{tabular}{|c|c|c|c|c|c|c|}
\hline \multirow{2}{*}{ LAB Strain } & \multicolumn{2}{|c|}{ Aspergillus flavus } & \multicolumn{2}{|c|}{ Aspergillus carbonarius } & \multirow{2}{*}{$\begin{array}{l}\text { I\% of } A . \\
\text { flavus }\end{array}$} & \multirow{2}{*}{$\begin{array}{c}\text { I\% of } A . \\
\text { carbonarius }\end{array}$} \\
\hline & GI\% & GI Category & GI\% & GI Category & & \\
\hline A1 & $50 \pm 3.5^{b}$ & 2 & $97 \pm 0.6^{a}$ & 4 & $40 \pm 1.5^{b}$ & $67 \pm 2.0^{b}$ \\
\hline A2 & $52 \pm 3.4^{b}$ & 3 & $85 \pm 0.8^{a}$ & 4 & $28 \pm 1.7^{b}$ & $80 \pm 1.0^{b}$ \\
\hline A3 & $50 \pm 3.5^{b}$ & 3 & $90 \pm 0.6^{a}$ & 4 & $25 \pm 2.0^{b}$ & $78 \pm 1.3^{b}$ \\
\hline A4 & $56 \pm 2.6^{b}$ & 3 & $89 \pm 1.4^{a}$ & 4 & $61 \pm 1.1^{a}$ & $94 \pm 2.9^{a}$ \\
\hline A5 & $63 \pm 2.1^{\mathrm{ab}}$ & 3 & $89 \pm 1.3^{a}$ & 4 & $59 \pm 1.4^{a}$ & $95 \pm 1.1^{\mathrm{a}}$ \\
\hline A6 & $56 \pm 2.5^{b}$ & 3 & $89 \pm 1.3^{a}$ & 4 & $58 \pm 1.0^{\mathrm{a}}$ & $95 \pm 1.1^{\mathrm{a}}$ \\
\hline A7 & $62 \pm 1.9^{a b}$ & 3 & $87 \pm 1.0^{a}$ & 4 & $58 \pm 9.4^{a}$ & $95 \pm 1.4^{\mathrm{a}}$ \\
\hline A8 & $68 \pm 1.7^{a}$ & 3 & $77 \pm 2.0^{a b c}$ & 4 & $57 \pm 1.1^{a}$ & $95 \pm 1.6^{a}$ \\
\hline A9 & $66 \pm 2.0^{a}$ & 3 & $81 \pm 1.6^{a}$ & 4 & $62 \pm 1.2^{a}$ & $94 \pm 1.3^{a}$ \\
\hline A10 & $70 \pm 1.7^{a}$ & 3 & $86 \pm 1.4^{a}$ & 4 & $58 \pm 1.1^{a}$ & $95 \pm 1.1^{\mathrm{a}}$ \\
\hline A11 & $70 \pm 1.7^{a}$ & 3 & $87 \pm 1.3^{a}$ & 4 & $56 \pm 1.2^{a}$ & $95 \pm 1.1^{a}$ \\
\hline A12 & $53 \pm 2.9^{b}$ & 3 & $71 \pm 2.3^{b c}$ & 3 & $54 \pm 1.1^{a}$ & $95 \pm 0,9^{a}$ \\
\hline A13 & $71 \pm 1.6^{a}$ & 3 & $83 \pm 1.4^{a}$ & 4 & $51 \pm 9.7^{a}$ & $94 \pm 1.2^{a}$ \\
\hline A14 & $68 \pm 1.8^{a}$ & 3 & $59 \pm 2.5^{c}$ & 3 & $54 \pm 1.1^{a}$ & $96 \pm 1.0^{\mathrm{a}}$ \\
\hline
\end{tabular}

* Values in the same column with at least one common letter $(a-c)$ showed no significant $(p>0.05)$ differences.

\subsection{Antioxidant Activity}

All the tested LAB, both as bacterial culture and CFS, displayed lower radical scavenging activity than the control (BHT) (Figure 6). When the whole bacterial cultures were tested, the scavenging activity against DPPH ranged between ca. 30\% (L. plantarum A2) and 83\% (E. faecalis A12). Compared to bacterial cultures, the CFS showed higher antioxidant activity, with values ranging from ca. $76 \%$ (E. faecalis A13) and 90\% (E. faecalis A10 and A12).

When the $\beta$-carotene bleaching assay was used, bacterial cultures of the tested LAB strains showed lower antioxidant activity (varying from ca. 30\% to 65\%) than the positive control at the beginning of incubation (Figure 7A). The antioxidant activity of the LAB cultures increased after $6 \mathrm{~h}$ of incubation. A further increase was found at $24 \mathrm{~h}$ just for E. faecalis A4 and A5, whereas the activity of the other strains decreased or remained constant. Compared to 6 or $24 \mathrm{~h}$ of incubation, all the bacterial cultures showed lower antioxidant activity at $48 \mathrm{~h}$. At this incubation time, the most active strains were $E$. faecalis A9, A10, A12, and A13. Overall, CFS showed higher antioxidant activity than the corresponding bacterial cultures, although lower than the control (Figure 7B). In detail, the strains belonging to the L. plantarum group (A1, A2, and A3) showed quite a constant antioxidant activity, regardless of the incubation time. Strains of E. faecalis showed higher activity than those of the L. plantarum group after 0 and $6 \mathrm{~h}$ of incubation. When incubation was prolonged to $48 \mathrm{~h}$, the antioxidant activity decreased for all the strains of E. faecalis, except for the strains A8 and A9, whose activity was constant. 


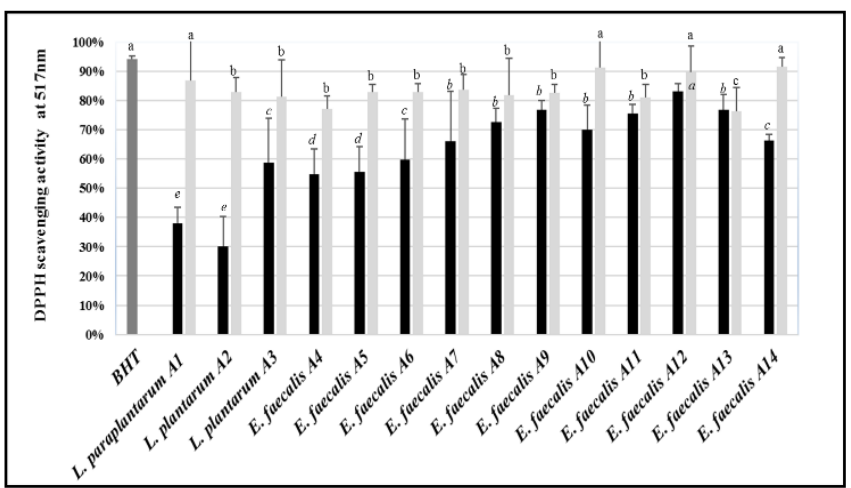

Figure 6. 2,2-DiPhenyl-1-PicrylHydrazyl (DPPH) radical scavenging activity (\%) of the LAB strains tested as whole cultures (black bars) or CFS (light grey bars). Butyl hydroxytoluene (BHT) was used as a positive control. The bars sharing one common letter (a-e) indicate not significantly $(p>0.05)$ different values of radical scavenging activity.

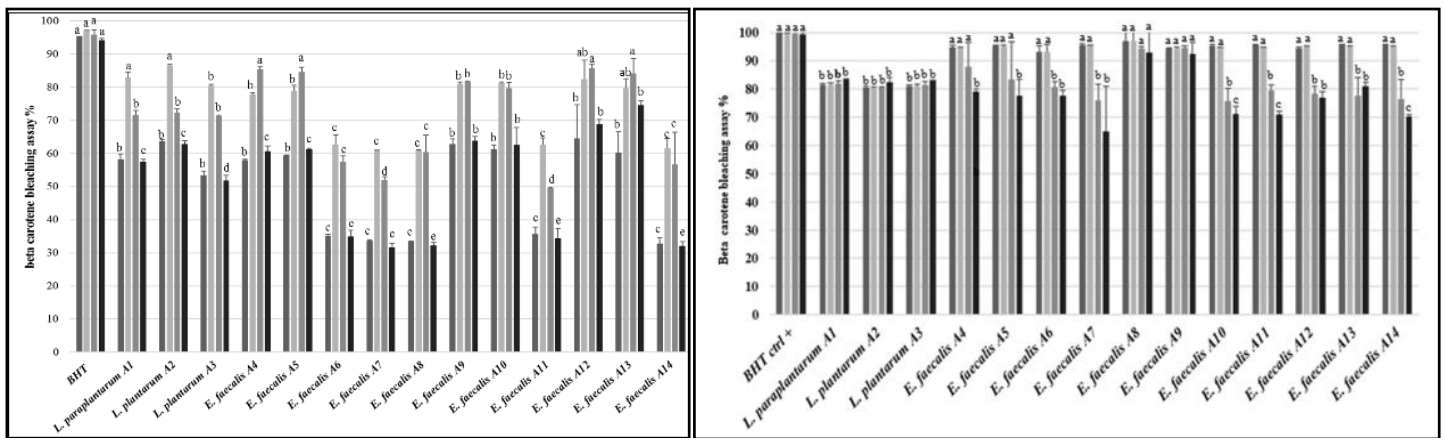

(A)

(B)

Figure 7. Antioxidant activity (\%) of the LAB strains, tested as whole cultures (A) or CFS (B), determined after 0 (dark grey), 6 (light grey), 24 (grey), or 48 h (black bars), using the $\beta$-carotene bleaching assay. BHT was used as a positive control. The bars sharing one common letter (a-e) indicate not significantly $(p>0.05)$ different values of antioxidant activity.

Antioxidant activity was also tested using the ferric reducing antioxidant power (FRAP method. Overall, whole bacterial cultures showed higher activity than the CFS. The three strain of the $L$. plantarum group had higher activity than those belonging to E. faecalis (Figure 8). When CFS was used, lower differences in antioxidant activity were found among the tested LAB strains, except for E. faecalis A4, which showed the lowest antioxidant potential. 




Figure 8. Antioxidant activity, expressed as absorbance at $700 \mathrm{~nm}$, of the LAB strains, tested as whole cultures (black) or CFS (grey bars), using the FRAP assay. L-cysteine was used as a positive control. The bars sharing one common letter $(\mathrm{a}-\mathrm{d})$ indicate not significantly $(p>0.05)$ different values of antioxidant activity.

\section{Discussion}

During human history, naturally fermented foods and beverages have been an important part of the diet. The majority of fermented food items are still produced using traditional protocols [52]. Although few issues have been related to the consumption of specific fermented foods, in most of cases they seem to benefit human health $[52,53]$. Microorganisms inhabiting fermented foods, either as naturally present or added as starters, represent the main link between consumption of these food and health benefits. Their importance dates back to the studies by Elie Metchnikoff about the correlations between consumption of fermented milks and longevity of individuals living in some Bulgarian regions [54]. Microbial consortia of fermented foods lead to the improvement of sensory, shelf-life, nutritional, and functional quality [53]. The potential probiotic activity of several fermentative bacteria (e.g., lactic acid bacteria, LAB) living in fermented foods has been reported. Lactobacillus and Enterococcus are among the most commonly used genera of probiotics [55]. Although most of applications of probiotic microorganisms for benefiting human health regard gastrointestinal and immune system functions, in the last decade the use of probiotics for preventing or even treating skin diseases (e.g., atopic dermatitis, actinic keratosis, fungal and bacterial infections) is attracting the attention of an increasing number of researchers [22,56-59].

In the current study, the probiotic potential of $14 \mathrm{LAB}$ isolated from zgougou, a fermented food based on Aleppo pine's seeds was assessed, as recommended by the FAO/WHO (2002). The screening was performed using in vitro tests, which represent the first step before starting the in vivo evaluation of health benefits. The strains belonging to the L. plantarum group or E. faecalis, showed no DNase, hemolytic, and gelatinase activities. The latter enzyme could be harmful in the case of the application of probiotic microorganisms to host districts, such as skin and gut [60,61]. In contrast with our results, production of gelatinase by pathogenic strains of E. faecalis has been previously observed [62-64].

The presence of genetic determinants of antibiotic resistance represents another issue, since they could be horizontally transferred to bacteria inhabiting the human gastrointestinal tract [65-68]. The LAB strains from zgougou were susceptible to chloramphenicol and tetracyclin. The gene transfer of resistance towards these two antibiotics is emerging for lactobacilli [69-71]. In addition, all the strains considered in this study were inhibited by three other antibiotics. In spite of the reported resistance to polimixin B by enterococcal strains [72], all the strains of E. faecalis tested in this study were inhibited by this antibiotic. Almost all the strains showed resistance to kanamycin and oxytetracyclin. A pattern of specific antibiotic resistance was recognized for strains the L. plantarum group, but not for strains of enterococci. In detail, lactobacilli resisted to five more antibiotics, besides kanamycin and oxytetracyclin. These results roughly confirm previous studies about antibiotic resistance in LAB $[35,72-74]$. However, the absence of antibiotic resistance determinants has been recently resulted from comparative genomic analysis of 50 strains of the L. plantarum group of various origin [75]. 
In addition, one previous report showed that 38 out of 54 strains of E. faecalis were susceptible to oxytetracyclin [72]. The absence of DNase and hemolytic activity and the susceptibility to most of the tested antibiotics satisfied some of the safety prerequisites [76-78] for the potential use of the LAB isolated from zgougou as probiotic bacteria.

Resistance to low $\mathrm{pH}$, bile salts, pepsin, and pancreatin and, just for eventual use as dietary supplements in aquaculture, high concentrations of $\mathrm{NaCl}$ are among the most important selection criteria for probiotics. The survival of potentially probiotic strains in the gastrointestinal juice and stomach acidity is a key functional assessment for their activity in the host [79-82]. The ability to survive stressing conditions that mimic the gastrointestinal digestion varied depending on the strains considered in this study, although enterococci showed higher resistance to pancreatin than lactobacilli. In addition, 7 out of 10 enterococci strains showed higher tolerance to bile salts, compared to lactobacilli. Similar results were previously reported for bacteria belonging to the same species tested in this study $[35,51,68,79,81,83]$.

The capacity of probiotic microorganisms to adhere to cell surface, produce biofilm, and auto-aggregate plays a pivotal role for colonization of host epithelia (e.g., intestinal, cutaneous), a pre-requisite to help host defense mechanisms against gut and skin infections [37,59]. The results obtained in this study showed that almost all the LAB strains displayed a very high performance of cell adhesion, auto-aggregation, and biofilm formation. Similar results were previously reported for Lactobacillus and Enterococcus species upon in vitro tests using polysterene, gut epithelial cells, or mucin $[35,68,73,84-88]$. Hydrophobicity often mediates and strengthens the surface adhesion ability of probiotic microorganisms. Indeed, some components of the microbial cell surface (e.g., glycoproteins, polysaccharides) show strong affinity to hydrophobic compounds [73,87-91]. In this study, most of the tested LAB were highly hydrophobic to n-hexadecane (non-polar solvent) and chloroform (a mono-polar and acidic solvent), whereas they showed lower affinity towards ethyl acetate (a mono-polar basic solvent). Analogous results were reported previously. For instance, Lactobacillus brevis had an average hydrophobicity towards chloroform and n-hexadecane, but very low hydrophobicity towards ethyl acetate. L. plantarum and L. paraplantarum showed high hydrophobic potential towards $n$-hexadecane, besides other non-polar solvents, such as toulene and xylene $[35,86,92]$. In addition, hydrophobicity of E. faecalis towards xylene and hexane had been previously shown $[93,94]$.

Cultivation of microorganisms for production and extraction of hydrolytic enzymes (lipase, amylase and esterase) is a currently valuable biotechnological solution for supplying enzymes for various uses $[60,61,95-100]$. The LAB strains tested in this study showed interesting, but strain-depending variable, enzyme activities, in accordance with previous studies on various species of lactobacilli. Those enzymes can help digestive process in animals and humans [101-103].

The ability to inhibit or inactivate undesired bacteria is one of the most attractive traits of potentially probiotic microorganisms. Antimicrobial activity of probiotics may play very important role in modulating gastrointestinal and cutaneous dysbiosis and related diseases [8,104-108]. In this study, the 14 LAB strains had strong growth-inhibiting attributes against at least 7 out of 10 target bacteria, responsible of either food-born disease (e.g., Listeria monocytogenes, Escherichia coli, Salmonella Typhimurium, Bacillus cereus) or skin infections (e.g., Micrococcus luteus, Staphylococcus aureus, Staphylococcus epidermidis). The LAB strains did not show bactericidal activity, but most of them could control over biofilm formation by the pathogenic bacteria. In agreement with our results, Lactobacillus sp. could inhibit the bacterial growth, and had anti-biofilm activity against L. monocytogenes, E. coli, $S$. Typhimurium, B. cereus, and S. aureus [86,109]. L. brevis showed a broad inhibitory spectrum against the same target bacteria used in this study, with the exception of M. luteus and Vibrio parahaemolyticus [35]. Antibacterial activity has been reported for enterococci too. E. faecalis inhibited the growth of S. aureus, E. faecalis, and E. coli [110]. E. durans and E. faecalis counteracted proliferation of L. monocytogenes, E. faecalis, E. coli, S. Typhimurium, Pseudomonas aeruginosa, B. cereus, and S. aureus [111]. Growth and biofilm formation by $V$. parahaemolyticus were inhibited by almost all the strains used in this study, in agreement with previous studies focused on Vibrio sp. [112-114]. 
The LAB strains isolated from zgougou were tested against two fungal species, Aspergillus carbonarius and Aspergillus flavus, causing diseases or metabolic disorders in gastrointestinal tract and skin. Aspergillosis is correlated to infections by the above-mentioned fungal species in immunocompromised individuals, including burn victims, neonates, individuals with cancer, and HIV infected populations [115-118]. Some studies suggested the existence of a correlation between aspergillosis and cancer development [119-121]. In this study, as assessed through two different assays, the two target fungi were sensitive, with different, strain-dependent degrees, to all the tested LAB and their CFS. In particular, CFS from strains of E. faecalis had the highest antifungal activity. This activity could be probably due to the negative influence of some compounds (e.g., organic acids) contained in CFS on fungal proliferation. Strains of E. faecium and E. faecalis were identified as potential bio-preservative agents to control over pathogenic molds in cereals, fermented foods, and dairy products [122,123]. In addition, CFS extracted from Lactobacillus sp. could reduce both the growth and toxin production of Aspergillus sp. [124-130].

Antioxidant activity represents an additional interesting trait in the selection pathway of candidate probiotic microorganisms. Oxidative stress, mainly caused by free radicals, contributes to carcinogenesis and ageing. Antioxidants may counteract the degenerative action triggered on the host by free radicals, thus provoking health benefits. Some antioxidant compounds produced by LAB act as scavengers of reactive oxygen species (ROS) and metal chelators [131,132]. The results obtained in this study showed that the LAB strains isolated from zgougou, especially used in the form of CFS, had good DPPH radical scavenging capacity, possibly due to their extracellular metabolites. The antioxidant activity depended on the strain. Their activity was also confirmed through the FRAP and $\beta$-carotene bleaching assays. The latter simulates the peroxidation of membrane lipid components (e.g., linoleic acid) [133]. In addition, using the $\beta$-carotene bleaching assay, CFS showed higher antioxidant activity than whole bacterial cultures. It may be hypothesized that CFS are rich in secondary metabolites and exopolysaccharides (EPS) displaying this biological activity [134]. EPS from L. plantarum and E. faecium could possess an important, dose-dependent radical scavenging activity [132,135]. In agreement with the results of this study, the antioxidant activity of Lactobacillus sp. [50,131,132,134,136-139] and Enterococcus sp. [140,141] decreased the accumulation of ROS during food fermentation. In addition, the lyophilized CFS of $E$. faecium disclosed high antioxidant activity [142] and strains of Enterococcus sp. displayed an excellent radical scavenging capacity, thanks to antioxidant compounds present in their supernatant [142].

Zgougou is one of the several fermented foods that thus far has received scarce attention, probably because it is mostly home-made. However, the scarce information does not necessarily mean that it cannot display beneficial, evidence-based effects [53]. Indeed, the results of this work highlight that zgougou represents an important reservoir of potentially probiotic LAB. Obviously, future studies should be addressed to confirm the health benefits of the LAB strains.

\section{Conclusions}

In this study, LAB strains were isolated for the first time from zgougou, a traditional Tunisian fermented food, and characterized for their potential probiotic traits. Interestingly, most of LAB strains belonged to E. faecalis; however, differently from most of the strains belonging to the same species but isolated from animal matrices, they did not show any particular pathogenic trait. Although there was no unique LAB strain, possessing at the highest level all the desirable probiotic traits, further studies could allow the assessment of the safe use of these LAB as: (i) Probiotic components tailored to prevention of gastrointestinal and skin diseases (through anti-inflammatory, anti-carcinogenic effects); (ii) starters for food fermentation; and/or (iii) food bio-preservatives.

Supplementary Materials: The following are available online at http://www.mdpi.com/2076-2607/7/12/709/s1.

Author Contributions: Conceptualization, J.M.; formal analysis, R.M.; investigation, J.M.; writing—original draft, F.M., J.M.; writing-review and editing, D.S.

Funding: This research received no external funding. 
Acknowledgments: The author thanks Maria De Angelis for useful discussions about the study.

Conflicts of Interest: The authors declare no conflict of interest.

\section{References}

1. Soccol, C.R.; Vandenberghe, L.P.D.; Spier, M.R.; Medeiros, A.B.P.; Yamaguishi, C.T.; Lindner, J.D.; Pandey, A.; Thomaz-Soccol, V. The potential of probiotics: A review. Food Technol. Biotechnol. 2010, 48, 413-434.

2. Oelschlaeger, T.A. Mechanisms of probiotic actions-A review. Int. J. Med. Microbiol. 2010, 300, 57-62. [CrossRef] [PubMed]

3. Abrunhosa, L.; Inês, A.; Rodrigues, A.I.; Guimarães, A.; Pereira, V.L.; Parpot, P.; Mendes-Faia, A.; Venâncio, A. Biodegradation of ochratoxin A by Pediococcus parvulus isolated from Douro wines. Int. J. Med. Microbiol. 2014, 188, 45-52. [CrossRef] [PubMed]

4. Le Lay, C.; Mounier, J.; Vasseur, V.; Weill, A.; Le Blay, G.; Barbier, G.; Coton, E. In vitro and in situ screening of lactic acid bacteria and propionibacteria antifungal activities against bakery product spoilage molds. Food Control 2016, 60, 247-255. [CrossRef]

5. Araújo, T.F.; Ferreira, C.L.d.L.F. The genus Enterococcus as probiotic: Safety concerns. Braz. Arch. Biol. Technol. 2013, 56, 457-466. [CrossRef]

6. Shetty, P.H.; Jespersen, L. Saccharomyces cerevisiae and lactic acid bacteria as potential mycotoxin decontaminating agents. Trends Food Sci. Technol. 2006, 17, 48-55. [CrossRef]

7. Rima, H.; Ismail, F. Antimicrobial and probiotic properties of yeasts: From fundamental to novel applications. Front. Microbiol. 2012, 3, 421.

8. O'Shea, E.F.; Cotter, P.D.; Stanton, C.; Ross, R.P.; Hill, C. Production of bioactive substances by intestinal bacteria as a basis for explaining probiotic mechanisms: Bacteriocins and conjugated linoleic acid. Int. J. Food Microbiol. 2012, 152, 189-205. [CrossRef]

9. Rathore, M.; Sharma, K. Probiotics and their Indian and global value: A review. World J. Pharm. Med. Res. 2017, 3, 43-54.

10. Van den Berg, D.J.; Smits, A.; Potn, B.; Ledeboer, A.M.; Kersters, K.; Verbake, J.M.; Verrips, C.T. Isolation, screening and identification of lactic acid bacteria from traditional food fermentation processes and culture collections. Food Biotechnol. 1993, 7, 189-205. [CrossRef]

11. Ali, A.A.; Mustafa, M.M. Isolation, characterization and identification of lactic acid bacteria from fermented sorghum dough used in Sudanese Kisra preparation. Pak. J. Nutr. 2009, 8, 1814-1818. [CrossRef]

12. Manini, F.; Casiraghi, M.C.; Poutanen, K.; Brasca, M.; Erba, D.; Plumed-Ferrer, C. Characterization of lactic acid bacteria isolated from wheat bran sourdough. LWT Food Sci. Technol. 2016, 66, 275-283. [CrossRef]

13. Alfonzo, A.; Ventimiglia, G.; Corona, O.; Di Gerlando, R.; Gaglio, R.; Francesca, N.; Moschetti, G.; Settanni, L. Diversity and technological potential of lactic acid bacteria of wheat flours. Food Microbiol. 2013, 36, 343-354. [CrossRef] [PubMed]

14. De Almeida Júnior, W.L.G.; Da Silva Ferrari, Í; De Souza, J.V.; Da Silva, C.D.A.; Da Costa, M.M.; Dias, F.S. Characterization and evaluation of lactic acid bacteria isolated from goat milk. Food Control 2015, 53, 96-103. [CrossRef]

15. Wang, D.; Liu, W.; Ren, Y.; De, L.; Zhang, D.; Yang, Y.; Bao, Q.; Zhang, H.; Menghe, B. Isolation and Identification of lactic acid bacteria from traditional dairy products in Baotou and Bayannur of midwestern inner Mongolia and q-PCR analysis of predominant species. Korean J. Food Sci. An. 2016, 36, 499. [CrossRef]

16. Verón, H.E.; Di Risio, H.D.; Isla, M.I.; Torres, S. Isolation and selection of potential probiotic lactic acid bacteria from Opuntia ficus-indica fruits that grow in Northwest Argentina. LWT Food Sci. Technol. 2017, 84, 231-240. [CrossRef]

17. Naeem, M.; Ilyas, M.; Haider, S.; Baig, S.; Saleem, M. Isolation characterization and identification of lactic acid bacteria from fruit juices and their efficacy against antibiotics. Pak. J. Bot. 2012, 44, 8.

18. Tajabadi, N.; Mardan, M.; Manap, M.Y.A.; Mustafa, S. Molecular identification of Lactobacillus spp. isolated from the honey comb of the honey bee (Apis dorsata) by 16S rRNA gene sequencing. J. Apic. Res. 2013, 52, 235-241. [CrossRef]

19. Ekundayo, F. Isolation and identification of lactic acid bacteria from rhizosphere soils of three fruit trees, fish and ogi. Int. J. Curr. Microbiol. Appl. Sci. 2014, 3, 991-998. 
20. Kaur, R.; Tiwari, S. Isolation, identification and characterization of Pediococcus pentosaceus LB44 and Weissella confusa LM85 for the presence of bacteriocin-like inhibitory substances (BLIS). Microbiology 2016, 85, 540-547. [CrossRef]

21. Fuchs-Tarlovsky, V.; Marquez-Barba, M.F.; Sriram, K. Probiotics in dermatologic practice. Nutr. J. 2016, 32, 289-295. [CrossRef] [PubMed]

22. Friedrich, A.D.; Paz, M.L.; Leoni, J.; Gonzalez Maglio, D.H. Message in a bottle: Dialog between intestine and skin modulated by probiotics. Int. J. Mol. Sci. 2017, 18, 1067. [CrossRef] [PubMed]

23. Tsitsoni, T.K. Seed quality characteristics of Pinus halepensis-seed germination strategy and early seedling growth. Web Ecol. 2009, 9, 72-76. [CrossRef]

24. Fekih, N.; Allali, H.; Merghache, S.; Chaïb, F.; Merghache, D.; El Amine, M.; Djabou, N.; Muselli, A.; Tabti, B.; Costa, J. Chemical composition and antibacterial activity of Pinus halepensis Miller growing in West Northern of Algeria. Asian Pac. J. Trop. Dis. 2014, 4, 97. [CrossRef]

25. Nasri, N.; Triki, S. Analyse des lipides des graines de pins de Tunisie (Pinus halepensis Mill. et Pinus pinea L.). Riv. Ital. Sostanze Grasse 2004, 81, 244-247.

26. Cheikh-Rouhou, S.; Hentati, B.; Besbes, S.; Blecker, C.; Deroanne, C.; Attia, H. Chemical composition and lipid fraction characteristics of Aleppo pine (Pinus halepensis Mill.) seeds cultivated in Tunisia. Food Sci. Technol. Int. 2006, 12, 407-415. [CrossRef]

27. Nahal, I. Taxonomie et aire géographique des pins du groupe halepensis. CIHEAM Options Méditerranéennes 1986, 1, 1-9.

28. Stendid, J.; Karlsson, J.O.; Hogberg, N. Intra-specific genetic variation in Heterobasidium annosum revealed by amplification of minisatellite DNA. Mycol. Res. 1994, 98, 57-63. [CrossRef]

29. Corsetti, A.; Lavermicocca, P.; Morea, M.; Baruzzi, F.; Tosti, N.; Gobbetti, M. Phenotypic and molecular identification and clustering of lactic acid bacteria and yeasts from wheat (species Triticum durum and Triticum aestivum) sourdoughs of Southern Italy. Int. J. Food Microbiol. 2001, 64, 95-104. [CrossRef]

30. Zapparoli, G.; Torriani, S.; and Dell'aglio, F. Differentiation of Lactobacillus sanfranciscensis strains by randomly amplified polymorphic DNA and pulsed-field gel electrophoresis. FEMS Microbiol. Lett. 1998, 166, 324-332. [CrossRef]

31. De Angelis, M.; Siragusa, S.; Berloco, M.; Caputo, L.; Settanni, L.; Alfonsi, G.; Amerio, M.; Grandi, A.; Ragni, A.; Gobbetti, M. Selection of potential probiotic lactobacilli from pig feces to be used as additives in pelleted feeding. Res. Microbiol. 2006, 157, 792-801. [CrossRef] [PubMed]

32. Di Cagno, R.; Rizzello, C.G.; Gagliardi, F.; Ricciuti, P.; Ndagijimana, M.; Francavilla, R.; Guerzoni, M.E.; Crecchio, C.; Gobbetti, M.; De Angelis, M. Different fecal microbiotas and volatile organic compounds in treated and untreated children with celiac disease. Appl. Environ. Microbiol. 2009, 75, 3963-3971. [CrossRef] [PubMed]

33. Naser, S.M.; Thompson, F.L.; Hoste, B.; Gevers, D.; Dawyndt, P.; Vancanneyt, M.; Swings, J. Application of multilocus sequence analysis (MLSA) for rapid identification of Enterococcus species based on rpoA and pheS genes. Microbiology 2005, 151, 2141-2150. [CrossRef] [PubMed]

34. Aguas, R.; Ferguson, N.M. Feature selection methods for identifying genetic determinants of host species in RNA viruses. PLoS Comput. Biol. 2013, 9, e1003254.

35. Thapa, N.; Pal, J.; Tamang, J.P. Microbial diversity in ngari, hentak and tungtap, fermented fish products of North-East India. World J. Microbiol. Biotechnol. 2004, 20, 599. [CrossRef]

36. Vesterlund, S.; Paltta, J.; Karp, M.; Ouwehand, A.C. Adhesion of bacteria to resected human colonic tissue: Quantitative analysis of bacterial adhesion and viability. Res. Microbiol. 2005, 156, 238-244. [CrossRef]

37. Taheur, F.B.; Kouidhi, B.; Fdhila, K.; Elabed, H.; Slama, R.B.; Mahdouani, K.; Bakhrouf, A.; Chaieb, K. Anti-bacterial and anti-biofilm activity of probiotic bacteria against oral pathogens. Microb. Pathog. 2016, 97, 213-220. [CrossRef]

38. Ambalam, P.; Kondepudi, K.K.; Nilsson, I.; Wadström, T.; Ljungh, Å. Bile stimulates cell surface hydrophobicity, Congo red binding and biofilm formation of Lactobacillus strains. FEMS Microbiol. Lett. 2012, $333,10-19$.

39. Del Re, B.; Sgorbati, B.; Miglioli, M.; Palenzona, D. Adhesion, autoaggregation and hydrophobicity of 13 strains of Bifidobacterium longum. Lett. Appl. Microbiol. 2000, 31, 438-442. [CrossRef]

40. Maria, G.; Sridhar, K.; Raviraja, N. Antimicrobial and enzyme activity of mangrove endophytic fungi of southwest coast of India. J. Agric. Technol. 2005, 1, 67-80. 
41. Carrim, A.J.I.; Barbosa, E.C.; Vieira, J.D.G. Enzymatic activity of endophytic bacterial isolates of Jacaranda decurrens Cham. (Carobinha-do-campo). Braz. Arch. Biol. Technol. 2006, 49, 353-359. [CrossRef]

42. Hashemi, S.M.B.; Mousavi-Khaneghah, A.; Kontominas, M.G.; Eş, I.; Sant'Ana, A.S.; Martinez, R.R.; Drider, D. Fermentation of sarshir (kaymak) by lactic acid bacteria: Antibacterial activity, antioxidant properties, lipid and protein oxidation and fatty acid profile. J. Sci. Food Agric. 2017, 97, 4595-4603. [CrossRef] [PubMed]

43. Cherif, A.; Sadfi-Zouaoui, N.; Eleuch, D.; Dhahri, A.B.O.; Boudabous, A. Pseudomonas isolates have in vitro antagonistic activity against the dermatophytes Trichophyton rubrum, Trichophyton mentagrophytes var interdigitale and Microsporum canis. J. Mycol. Med. 2009, 19, 178-184. [CrossRef]

44. Whipps, J.M. Effect of media on growth and interactions between a range of soil-borne glasshouse pathogens and antagonistic fungi. New Phytol. 1987, 107, 127-142. [CrossRef]

45. Korsten, L.; De Jager, E.; De Villiers, E.; Lourens, A.; Kotze, J.; Wehner, F. Evaluation of bacterial epiphytes isolated from avocado leaf and fruit surfaces. Plant Dis. 1997, 9, 1149.

46. Wang, H.; Yan, Y.; Wang, J.; Zhang, H.; Qi, W. Production and characterization of antifungal compounds produced by Lactobacillus plantarum IMAU10014. PLoS ONE 2012, 7, e29452. [CrossRef]

47. CLSI. Performance Standards for Antimicrobial Disc Susceptibility Tests, 13th ed.; CLSI standard M02; Clinical and Laboratory Standards Institute: Wayne, PA, USA, 2018.

48. Bougatef, A.; Nedjar-Arroume, N.; Manni, L.; Ravallec, R.; Barkia, A.; Guillochon, D.; Nasri, M. Purification and identification of novel antioxidant peptides from enzymatic hydrolysates of sardinelle (Sardinella aurita) by-products proteins. Food Chem. 2010, 118, 559-565. [CrossRef]

49. Trabelsi, I.; Ktari, N.; Slima, S.B.; Triki, M.; Bardaa, S.; Mnif, H.; Salah, R.B. Evaluation of dermal wound healing activity and in vitro antibacterial and antioxidant activities of a new exopolysaccharide produced by Lactobacillus sp. Ca6. Int. J. Biol. Macromol. 2017, 103, 194-201. [CrossRef]

50. Son, S.-H.; Yang, S.-J.; Jeon, H.-L.; Yu, H.-S.; Lee, N.-K.; Park, Y.-S.; Park, H.-D. Antioxidant and immunostimulatory effect of potential probiotic Lactobacillus paraplantarum SC61 isolated from Korean traditional fermented food, jangajji. Microb. Pathog. 2018, 125, 486-492. [CrossRef]

51. Tamang, J.P.; Shin, D.-H.; Jung, S.-J.; Chae, S.-W. Functional properties of microorganisms in fermented foods. Front. Microbiol. 2016, 7, 578. [CrossRef]

52. Chilton, S.N.; Burton, J.P.; Reid, G. Inclusion of fermented foods in food guides around the world. Nutrients 2015, 7, 390-404. [CrossRef] [PubMed]

53. Metchnikoff, E. The Prolongation of Life: Optimistic Studies; G.P. Putnam's Sons: New York, NY, USA, 1908.

54. Derrien, M.; van Hylckama Vlieg, J.E. Fate activity, and impact of ingested bacteria within the human gut microbiota. Trends Microbiol. 2015, 23, 354-366. [CrossRef] [PubMed]

55. Naik, S.; Bouladoux, N.; Linehan, J.L.; Han, S.J.; Harrison, O.J.; Wilhelm, C.; Conlan, S.; Himmelfarb, S.; Byrd, A.L.; Deming, C. Commensal-dendritic-cell interaction specifies a unique protective skin immune signature. Nature 2015, 520, 104. [CrossRef]

56. Que, S.K.T.; Zwald, F.O.; Schmults, C.D. Cutaneous squamous cell carcinoma: Incidence, risk factors, diagnosis, and staging. J. Am. Acad. Dermatol. 2018, 78, 237-247. [CrossRef]

57. Vuong, C.; Otto, M. Staphylococcus epidermidis infections. Microbes Infect. 2002, 4, 481-489. [CrossRef]

58. Nole, K.L.B.; Yim, E.; Keri, J.E. Probiotics and prebiotics in dermatology. J. Am. Acad. Dermatol. 2014, 71, 814-821. [CrossRef]

59. Del Papa, M.F.; Hancock, L.E.; Thomas, V.C.; Perego, M. Full activation of Enterococcus faecalis gelatinase by a C-terminal proteolytic cleavage. J. Bacterial. 2007, 189, 8835-8843. [CrossRef]

60. Nishida, S.; Ishii, M.; Nishiyama, Y.; Abe, S.; Ono, Y.; Sekimizu, K. Lactobacillus paraplantarum 11-1 isolated from rice bran pickles activated innate immunity and improved survival in a silkworm bacterial infection model. Front. Microbiol. 2017, 8, 436. [CrossRef]

61. Qin, X.; Singh, K.V.; Weinstock, G.M.; Murray, B.E. Effects of Enterococcus faecalis fsr genes on production of gelatinase and a serine protease and virulence. Infect. Immun. 2000, 68, 2579-2586. [CrossRef]

62. Annette, C.A.; Daniel, J.; Ingrid, H.; Lamprini, K.; Johan, W.; Elmar, H.; Nicole, A.; Kirstin, V.; Annette, W.; Al-Ahmad, A. Enterococcus faecalis from food, clinical specimens, and oral sites: Prevalence of virulence factors in association with biofilm formation. Front. Microbiol. 2016, 6, 1534.

63. Koel, B.; Puja, S.; Joshi, S.R. Co-occurrence of antimicrobial resistance and virulence determinants in enterococci isolated from traditionally fermented fish products. J. Glob. Antimicrob. Resist. 2019, 17, 79-83. 
64. EFSA Panel on Additives and Products or Substances used in Animal Feed (FEEDAP). Guidance on the assessment of bacterial susceptibility to antimicrobials of human and veterinary importance. EFSA J. 2012, 10, 2740.

65. EFSA Panel on Additives and Products or Substances used in Animal Feed (FEEDAP). Opinion of the scientific panel on additives and products or substances used in animal feed on the updating of the criteria used in assessment of bacteria for resistance to antibiotics of human and veterinary importance. EFSA J. 2005, 223, 1-12.

66. Ammor, M.S.; Mayo, B. Selection criteria for lactic acid bacteria to be used as functional starter cultures in dry sausage production: An update. Meat Sci. 2007, 76, 138-146. [CrossRef]

67. Endo, A.; Sasaki, F.; Maeno, S.; Kanesaki, Y.; Hamaguchi, Y.; Torres, G.A.; Tomita, S.; Nakagawa, J. In vitro and in silico characterisation of Lactobacillus paraplantarum D2-1, a starter culture for soymilk fermentation. Int. J. Food Sci. Nutr. 2018, 69, 857-869. [CrossRef]

68. Ahn, C.; Collins-Thompson, D.; Duncan, C.; Stiles, M.E. Mobilization and location of the genetic determinant of chloramphenicol resistance from Lactobacillus plantarum caTC2R. Plasmid 1992, 27, 169-176. [CrossRef]

69. Danielsen, M.; Wind, A. Susceptibility of Lactobacillus spp. to antimicrobial agents. Int. J. Food Microbiol. 2003, 82, 1-11. [CrossRef]

70. Roberts, M.C. Update on acquired tetracycline resistance genes. FEMS Microbiol. Lett. 2005, 245, $195-203$. [CrossRef]

71. de Fátima Silva Lopesa, M.; Ribeiro, T.; Abrantes, M.; Figueiredo Marques, J.J.; Tenreiro, R.; Barreto Crespo, M.T. Antimicrobial resistance profiles of dairy and clinical isolates and type strains of enterococci. Int. J. Food Microbiol. 2005, 103, 191-198. [CrossRef]

72. Nueno-Palop, C.; Narbad, A. Probiotic assessment of Enterococcus faecalis CP58 isolated from human gut. Int. J. Food Microbiol. 2011, 145, 390-394. [CrossRef]

73. Muñoz, M.dC.C.; Benomar, N.; Lerma, L.L.; Gálvez, A.; Abriouel, H. Antibiotic resistance of Lactobacillus pentosus and Leuconostoc pseudomesenteroides isolated from naturally-fermented Aloreña table olives throughout fermentation process. Int. J. Food Microbiol. 2014, 172, 110-118. [CrossRef] [PubMed]

74. Moreno, M.F.; Sarantinopoulos, P.; Tsakalidou, E.; De Vuyst, L. The role and application of enterococci in food and health. Int. J. Food Microbiol. 2006, 106, 1-24. [CrossRef] [PubMed]

75. Eliane, E.; Patricia Jeanne, dS.M.M.; João, F.G.; Evanovich, E.; de Souza Mendonça Mattos, P.J.; Farias Guerreiro, J. Comparative genomic analysis of Lactobacillus plantarum: An overview. Int. J. Genom. 2019, $2019,4973214$.

76. FAO/WHO. Joint FAO/WHO Working Group Report on Drafting Guidelines for the Evaluation of Probiotics in Food; FAO/WHO: London, ON, Canada, 2002.

77. Oh, Y.J.; Jung, D.S. Evaluation of probiotic properties of Lactobacillus and Pediococcus strains isolated from Omegisool, a traditionally fermented millet alcoholic beverage in Korea. LWT Food Sci. Technol. 2015, 63, 437-444. [CrossRef]

78. Foulquié, M.M.; Callewaert, R.; Devreese, B.; Van Beeumen, J.; De Vuyst, L. Isolation and biochemical characterisation of enterocins produced by enterococci from different sources. J. Appl. Microbiol. 2003, 94, 214-229. [CrossRef] [PubMed]

79. Tokatlı, M.; Gülgör, G.; Bağder Elmacı, S.; Arslankoz İşleyen, N.; Özçelik, F. In vitro properties of potential probiotic indigenous lactic acid bacteria originating from traditional pickles. BioMed Res. Int. 2015, 315819.

80. Fisher, K.; Phillips, C. The ecology, epidemiology and virulence of Enterococcus. Microbiology 2009, 155, 1749-1757. [CrossRef]

81. Mishra, A.K.; Ghosh, A.R. Characterization of functional, safety, and probiotic properties of Enterococcus faecalis AG5 isolated from wistar rat, demonstrating adherence to HCT 116 cells and gastrointestinal survivability. Probiotics Antimicrob. Proteins 2018, 10, 435-445. [CrossRef]

82. Cui, X.; Shi, Y.; Gu, S.; Yan, X.; Chen, H.; Ge, J. Antibacterial and antibiofilm activity of lactic acid bacteria isolated from traditional artisanal milk cheese from northeast China against enteropathogenic bacteria. Probiotics Antimicrob. Proteins 2017, 10, 601-610. [CrossRef]

83. Lleò, M.dM.; Bonato, B.; Benedetti, D.; Canepari, P. Survival of enterococcal species in aquatic environments. FEMS Microbiol. Ecol. 2005, 54, 189-196. [CrossRef] 
84. Liu, L.; Wu, R.; Zhang, J.; Li, P. Overexpression of LuxS promotes stress resistance and biofilm formation of Lactobacillus paraplantarum L-ZS9 by regulating the expression of multiple genes. Front. Microbiol. 2018, 9, e02628. [CrossRef] [PubMed]

85. Meira, S.M.M.; Helfer, V.E.; Velho, R.V.; Lopes, F.C.; Brandelli, A. Probiotic potential of Lactobacillus spp. isolated from Brazilian regional ovine cheese. J. Dairy Res. 2012, 79, 119-127. [CrossRef] [PubMed]

86. Ishibashi, N.; Yamazaki, S. Probiotics and safety. Am. J. Clin. Nutr. 2001, 73, 465-470. [CrossRef] [PubMed]

87. Lauková, A.; Kandričáková, A.; Buňková, L.; Pleva, P.; Ščerbová, J. Sensitivity to enterocins of biogenic amine-producing faecal enterococci from ostriches and pheasants. Probiotics Antimicrob. Proteins 2017, 9, 483-491. [CrossRef] [PubMed]

88. Van Zyl, W.; Deane, S.; Dicks, L. Enterococcus mundtii ST4SA and Lactobacillus plantarum 423 excludes Listeria monocytogenes from the GIT, as shown by bioluminescent studies in mice. Benefic. Microbes 2016, 7, 227-235. [CrossRef]

89. Schär-Zammaretti, P.; Ubbink, J. The cell wall of lactic acid bacteria: Surface constituents and macromolecular conformations. Biophys. J. 2003, 85, 4076-4092. [CrossRef]

90. Osmanagaoglu, O.; Kiran, F.; Ataoglu, H. Evaluation of in vitro probiotic potential of Pediococcus pentosaceus OZF isolated from human breast milk. Probiotics Antimicrob. Proteins 2010, 2, 162-174. [CrossRef]

91. Devi, S.M.; Aishwarya, S.; Halami, P.M. Discrimination and divergence among Lactobacillus plantarum-group (LPG) isolates with reference to their probiotic functionalities from vegetable origin. Syst. Appl. Microbiol. 2016, 39, 562-570. [CrossRef]

92. Al Atya, A.K.; Drider-Hadiouche, K.; Ravallec, R.; Silvain, A.; Vachee, A.; Drider, D. Probiotic potential of Enterococcus faecalis strains isolated from meconium. Front. Microbiol. 2015, 6, 227. [CrossRef]

93. Hyrslova, I.; Krausova, G.; Bartova, J.; Kolesar, L.; Jaglic, Z.; Stankova, B.; Curda, L. Characterization of Enterococcus faecium CCDM 922 in respect of its technological and probiotic properties. Int. J. Curr. Microbiol. Appl. Sci. 2016, 5, 474-482. [CrossRef]

94. De Vuyst, L.; Moreno, M.F.; Revets, H. Screening for enterocins and detection of hemolysin and vancomycin resistance in enterococci of different origins. Int. J. Food Microbiol. 2003, 84, 299-318. [CrossRef]

95. Thakkar, P.; Modi, H.; Prajapati, J. Isolation, characterization and safety assessment of lactic acid bacterial isolates from fermented food products. Int. J. Curr. Microbiol. Appl. Sci. 2015, 4, 713-725.

96. Meyers, S.; Cuppett, S.; Hutkins, R. Lipase production by lactic acid bacteria and activity on butter oil. Food Microbiol. 1996, 13, 383-389. [CrossRef]

97. Hanchi, H.; Mottawea, W.; Sebei, K.; Hammami, R. The genus Enterococcus: Between probiotic potential and safety concerns-An update. Front. Microbiol. 2018, 9, 1791. [CrossRef]

98. Matthews, A.; Grimaldi, A.; Walker, M.; Bartowsky, E.; Grbin, P.; Jiranek, V. Lactic acid bacteria as a potential source of enzymes for use in vinification. Appl. Environ. Microbiol. 2004, 70, 5715-5731. [CrossRef]

99. Askarian, F.; Kousha, A.; Salma, W.; Ringø, E. The effect of lactic acid bacteria administration on growth, digestive enzyme activity and gut microbiota in Persian sturgeon (Acipenser persicus) and beluga (Huso huso) fry. Aquacult. Nutr. 2011, 17, 488-497. [CrossRef]

100. Fossi, B.T.; Tavea, F. Application of Amylolytic Lactobacillus Fermentum 04BBA19 in Fermentation for Simultaneous Production of Thermostable Alpha-Amylase and Lactic Acid. In Lactic Acid Bacteria-R \& D for Food, Health and Livestock Purposes; Kongo, M., Ed.; IntechOpen: London, UK, 2013. [CrossRef]

101. Padmavathi, T.; Bhargavi, R.; Priyanka, P.R.; Niranjan, N.R.; Pavitra, P.V. Screening of potential probiotic lactic acid bacteria and production of amylase and its partial purification. J Genet. Eng. Biotechnol. 2018, 16, 357-362. [CrossRef]

102. Kalui, C.; Mathara, J.; Kutima, P.; Kiiyukia, C.; Wongo, L. Functional characteristics of Lactobacillus plantarum and Lactobacillus rhamnosus from ikii, a Kenyan traditional fermented maize porridge. Afr. J. Biotechnol. 2009, 8, 4363-4373.

103. Kumar, B.B.; Claes, I.J.; Lebeer, S. Functional mechanisms of probiotics. J. Microbiol. Biotechnol. Food Sci. 2015, $4,321-327$.

104. Ouwehand, A.C.; Lahtinen, S.; Tiihonen, K. The potential of probiotics and prebiotics for skin health. In Textbook of Aging Skin; Farage, M., Miller, K., Maibach, H., Eds.; Springer: Berlin, Germany, 2015; pp. 1299-1313.

105. O'Neill, C.A.; Monteleone, G.; McLaughlin, J.T.; Paus, R. The gut-skin axis in health and disease: A paradigm with therapeutic implications. BioEssays 2016, 38, 1167-1176. [CrossRef] 
106. Seite, S.; Bieber, T. Barrier function and microbiotic dysbiosis in atopic dermatitis. Clin. Cosmet. Investig. Dermatol. 2015, 8, 479. [CrossRef] [PubMed]

107. de Oliveira, G.L.V.; Leite, A.Z.; Higuchi, B.S.; Gonzaga, M.I.; Mariano, V.S. Intestinal dysbiosis and probiotic applications in autoimmune diseases. Immunology 2017, 152, 1-12. [CrossRef] [PubMed]

108. Gómez, N.C.; Ramiro, J.M.; Quecan, B.X.; de Melo Franco, B.D. Use of potential probiotic lactic acid bacteria (LAB) biofilms for the control of Listeria monocytogenes, Salmonella Typhimurium, and Escherichia coli O157: H7 biofilms formation. Front. Microbiol. 2016, 7, 863. [CrossRef] [PubMed]

109. Belgacem, Z.B.; Abriouel, H.; Omar, N.B.; Lucas, R.; Martínez-Canamero, M.; Gálvez, A.; Manai, M. Antimicrobial activity, safety aspects, and some technological properties of bacteriocinogenic Enterococcus faecium from artisanal Tunisian fermented meat. Food Control 2010, 21, 462-470. [CrossRef]

110. Pieniz, S.; Andreazza, R.; Anghinoni, T.; Camargo, F.; Brandelli, A. Probiotic potential, antimicrobial and antioxidant activities of Enterococcus durans strain LAB18s. Food Control 2014, 37, 251-256. [CrossRef]

111. Kaur, S.; Sharma, P.; Kalia, N.; Singh, J.; Kaur, S. Anti-biofilm properties of the fecal probiotic Lactobacilli against Vibrio spp. Front. Cell. Infect. Microbiol. 2018, 8, 120. [CrossRef]

112. Vidya, R.; Iyer, P. Antagonistic activity of probiotic organism against Vibrio cholerae and Cryptococcus neoformans. Malays. J. Microbiol. 2010, 6, 41-46.

113. Simonetta, A.; Moragues de Velasco, L.; Frison, L. Antibacterial activity of enterococci strains against Vibrio cholerae. Lett. Appl. Microbiol. 1997, 24, 139-143. [CrossRef]

114. Venkatesan, P.; Perfect, J.R.; Myers, S.A. Evaluation and management of fungal infections in immunocompromised patients. Dermatol. Ther. 2005, 18, 44-57. [CrossRef]

115. Hedayati, M.; Pasqualotto, A.; Warn, P.; Bowyer, P.; Denning, D. Aspergillus flavus: Human pathogen, allergen and mycotoxin producer. Microbiology 2007, 153, 1677-1692. [CrossRef]

116. Bongomin, F.; Batac, C.; Richardson, M.D.; Denning, D.W. A review of onychomycosis due to Aspergillus species. Mycopathologia 2018, 183, 485-493. [CrossRef] [PubMed]

117. Baddley, J.W. Clinical risk factors for invasive aspergillosis. Med. Mycol. 2011, 49, 7-12. [CrossRef] [PubMed]

118. Klich, M.A. Aspergillus flavus: The major producer of aflatoxin. Mol. Plant Pathol. 2007, 8, 713-722. [CrossRef] [PubMed]

119. IARC. Monographs on The Evaluation of Carcinogenic Risks to Humans; $N^{\circ} 82$. IARC: Some traditional herbal medicines, some mycotoxins, naphthalene and styrene; International Agency for Research on Cancer: Lyon, France, 2002.

120. Kamei, K.; Watanabe, A. Aspergillus mycotoxins and their effect on the host. Med. Mycol. 2005, 43, 95-99. [CrossRef]

121. Kuwaki, S.; Ohhira, I.; Takahata, M.; Murata, Y.; Tada, M. Antifungal activity of the fermentation product of herbs by lactic acid bacteria against tinea. J. Biosci. Bioeng. 2002, 94, 401-405. [CrossRef]

122. Djaaboub, S.; Moussaoui, A.; Meddah, B.; Makhloufi, S.; Gouri, S.; El Khatib, R. Antifungal activity of some indigenous lactic acid bacteria isolated from soft wheat. J. Pure Appl. Microbiol. 2018, 12, 111-118. [CrossRef]

123. Cortés-Zavaleta, O.; López-Malo, A.; Hernández-Mendoza, A.; García, H. Antifungal activity of lactobacilli and its relationship with 3-phenyllactic acid production. Int. J. Food Microbiol. 2014, 173, 30-35. [CrossRef]

124. Sangmanee, P.; Hongpattarakere, T. Inhibitory of multiple antifungal components produced by Lactobacillus plantarum K35 on growth, aflatoxin production and ultrastructure alterations of Aspergillus flavus and Aspergillus parasiticus. Food Control 2014, 40, 224-233. [CrossRef]

125. Belkacem-Hanfi, N.; Fhoula, I.; Semmar, N.; Guesmi, A.; Perraud-Gaime, I.; Ouzari, H.-I.; Boudabous, A.; Roussos, S. Lactic acid bacteria against post-harvest moulds and ochratoxin A isolated from stored wheat. Biol. Control 2014, 76, 52-59. [CrossRef]

126. Marie, K.P.; Ngoufack, F.Z.; Edith, M.F.K.; Ciobotaru, O.; Matei, F.; Cornea, C.P.; Israel, R.F. Antifungal activity of lactic acid bacteria isolated from peanuts, gari, and orange fruit juice against food aflatoxigenic molds. Food Biotechnol. 2018, 32, 237-256. [CrossRef]

127. Cosentino, S.; Viale, S.; Deplano, M.; Fadda, M.E.; Pisano, M.B. Application of autochthonous Lactobacillus strains as bio-preservatives to control fungal spoilage in caciotta cheese. BioMed Res. Int. 2018, 2018, 3915615. [CrossRef] [PubMed]

128. Guimarães, A.; Santiago, A.; Teixeira, J.A.; Venâncio, A.; Abrunhosa, L. Anti-aflatoxigenic effect of organic acids produced by Lactobacillus plantarum. Int. J. Food Microbiol. 2018, 264, 31-38. [CrossRef] [PubMed] 
129. Kim, J.D. Antifungal activity of lactic acid bacteria isolated from Kimchi against Aspergillus fumigatus. Mycobiology 2005, 33, 210-214. [CrossRef] [PubMed]

130. Lasrado, L.D.; Gudipati, M. Antioxidant property of symbiotic combination of Lactobacillus sp. and wheat bran xylo-oligosaccharides. J. Food Sci. Technol. 2015, 52, 4551-4557. [CrossRef] [PubMed]

131. Liu, Y.; Chen, H.; Chen, W.; Zhong, Q.; Zhang, G.; Chen, W. Beneficial effects of tomato juice fermented by Lactobacillus plantarum and Lactobacillus casei: Antioxidation, antimicrobial effect, and volatile profiles. Molecules 2018, 23, 2366. [CrossRef] [PubMed]

132. Ferreira, A.; Proença, C.; Serralheiro, M.; Araujo, M. The in vitro screening for acetylcholinesterase inhibition and antioxidant activity of medicinal plants from Portugal. J. Ethnopharmacol. 2006, 108, 31-37. [CrossRef] [PubMed]

133. Ahmad, A.; Yap, W.B.; Kofli, N.T.; Ghazali, A.R. Probiotic potentials of Lactobacillus plantarum isolated from fermented durian (Tempoyak), a Malaysian traditional condiment. Food Sci. Nutr. 2018, 6, 1370-1377. [CrossRef] [PubMed]

134. Abdhul, K.; Ganesh, M.; Shanmughapriya, S.; Kanagavel, M.; Anbarasu, K.; Natarajaseenivasan, K. Antioxidant activity of exopolysaccharide from probiotic strain Enterococcus faecium (BDU7) from Ngari. Int. J. Biol. Macromol. 2014, 70, 450-454. [CrossRef]

135. Kaizu, H.; Sasaki, M.; Nakajima, H.; Suzuki, Y. Effect of antioxidative lactic acid bacteria on rats fed a diet deficient in vitamin E. J. Dairy Sci. 1993, 76, 2493-2499. [CrossRef]

136. Parrella, A.; Caterino, E.; Cangiano, M.; Criscuolo, E.; Russo, C.; Lavorgna, M.; Isidori, M. Antioxidant properties of different milk fermented with lactic acid bacteria and yeast. Int. J. Food Sci. Technol. 2012, 47, 2493-2502. [CrossRef]

137. Das, D.; Goyal, A. Antioxidant activity and $\gamma$-aminobutyric acid (GABA) producing ability of probiotic Lactobacillus plantarum DM5 isolated from Marcha of Sikkim. LWT Food Sci. Technol. 2015, 61, 263-268. [CrossRef]

138. Prosekov, A.Y.; Dyshlyuk, L.S.; Milentieva, I.S.; Sykhikh, S.A.; Babich, O.O.; Ivanova, S.A.; Pavsky, V.A.; Shishin, M.V.; Matskova, L.V. Antioxidant and antimicrobial activity of bacteriocin-producing strains of lactic acid bacteria isolated from the human gastrointestinal tract. Prog. Nutr. 2017, 19, 67-80.

139. Lin, M.Y.; Yen, C.L. Antioxidative ability of lactic acid bacteria. J. Agric. Food Chem. 1999, 47, 1460-1466. [CrossRef] [PubMed]

140. Pieniz, S.; Okeke, B.C.; Andreazza, R.; Brandelli, A. Evaluation of selenite bioremoval from liquid culture by Enterococcus species. Microbiol. Res. 2011, 166, 176-185. [CrossRef]

141. Divyashri, G.; Krishna, G.; Prapulla, S. Probiotic attributes, antioxidant, anti-inflammatory and neuromodulatory effects of Enterococcus faecium CFR 3003: In vitro and in vivo evidence. J. Med. Microbiol. 2015, 64, 1527-1540. [CrossRef]

142. Pieniz, S.; Andreazza, R.; Okeke, B.C.; Camargo, F.A.d.O.; Brandelli, A. Antimicrobial and antioxidant activities of Enterococcus species isolated from meat and dairy products. Braz. J. Microbiol. 2015, 75, 923-931. [CrossRef]

(C) 2019 by the authors. Licensee MDPI, Basel, Switzerland. This article is an open access article distributed under the terms and conditions of the Creative Commons Attribution (CC BY) license (http://creativecommons.org/licenses/by/4.0/). 